\title{
Linguística Sistêmico-Funcional como uma teoria para análise de dados em Linguística Aplicada: escrita reflexiva do aluno-mestre
}

\author{
Systemic Functional Linguistics as a theory \\ for data analysis in Applied Linguistics: \\ teacher-trainee's reflexive writing
}

Wagner Rodrigues SIIVA

(Universidade Federal do Tocantins, Campus de Araguaína)

\section{RESUMO}

Investigamos algumas representações sobre professores da escola básica na escrita reflexiva profissional elaborada por professores em formação inicial, no estágio supervisionado obrigatório da licenciatura. Ao identificarmos as representações mencionadas, também caracterizamos a referida escrita e evidenciamos a relevância desse registro acadêmico para a formação crítica do professor. Tais objetivos foram alcançados a partir da articulação entre pressupostos teóricos da Linguística SistêmicoFuncional, em especial o conceito de contexto de cultura, e da abordagem transdisciplinar da Linguística Aplicada. Os resultados revelaram um esforço de invisibilização dos professores no registro investigado, os quais parecem não serem representados como interlocutores dos professores em formação inicial.

Palavras-chave: contexto; cultura; formação do professor; letramento. 


\section{ABSTRACT}

We investigated some representations about basic school teachers on the reflexive professional writing elaborated by teacher-trainees who were enrolled in the supervised compulsory teacher-training subject. By the identification of the representations made, we also characterized the writing mentioned and found out the relevance of this academic written register to the teacher's critical education. These objectives were achieved by the articulation between Systemic Functional Linguistics, especially the concept of context of culture, and the transdisciplinary approach of Applied Linguistics. The results showed an effort to render invisible the teachers in the register investigated. They seem not to be represented as teacher-trainee's interlocutors.

Key-words: context; culture; teacher education; literacy.

\section{Introdução}

Este artigo traz resultados de investigações científicas desenvolvidas no grupo de pesquisa "Práticas de Linguagens em Estágios Supervisionados" - PLES (UFT/CNPq) ${ }^{1}$. Tais investigações estão situadas na área da educação linguística, uma vez que a escrita reflexiva profissional, produzida por professores em formação inicial nas licenciaturas brasileiras, é investigada a partir da abordagem transdisciplinar de Linguística Aplicada (LA), tendo a Linguística Sistêmico-Funcional (LSF) como teoria de análise linguística dos dados escritos. O fortalecimento do letramento desse professor em formação, na academia e para o futuro local de trabalho, corresponde ao principal propósito das pesquisas realizadas.

A abordagem transdisciplinar da LA é justificada pelo propósito investigativo mencionado e pela natureza dos dados selecionados, a saber: relatórios de estágio supervisionado produzidos como trabalhos escritos finais por professores em formação inicial, aqui denominados

1. Esta pesquisa está vinculada ao projeto de pós-doutorado intitulado "Representações de professores da escola básica em relatórios de estágio supervisionado das licenciaturas: da gramática ao discurso, realizado na The Hong Kong Polytechnic University - PolyU (Bolsista CAPES - BEX 11536/12-8). 
de alunos-mestre, no estágio supervisionado obrigatório das Licenciaturas. A transdisciplinaridade é construída a partir do uso de categorias teórico-analíticas de diferentes áreas do conhecimento, em função de demandas investigativas instauradas a partir do exame dos relatórios selecionados. Alguns desdobramentos teóricos podem surgir a partir dos resultados produzidos de pesquisa. Em outros termos, a investigação não precisa se restringir à confirmação ou ao fortalecimento das teorias de referência, recategorizações ou reformulações conceptuais são esperadas.

A LSF é o principal referencial teórico assumido para realização da microanálise dos relatórios (Halliday 2003[1973], 1989; Hasan 2009, 2003, 1989; Martin e White 2005; Halliday e Matthiessen 2014; Thompson 2014), o qual é contextualizado a partir de referenciais teóricos sobre estudos do letramento (Kleiman 2009; 2006) e ensino reflexivo na formação do professor, sendo esses últimos mobilizados de diferentes disciplinas ou campos do conhecimento, como Linguística Aplicada (Edge 2011; Liberali 2004; Magalhães e Celani 2005) Educação (Grant e Zeichner 1984; Perrenoud 2002; Schön 1983; Zeichner 2008) e Escrita Criativa (Hunt e Sampson 2006).

Neste texto, respondemos os seguintes objetivos de pesquisa: (i) apresentação de um percurso investigativo possível para pesquisa transdisciplinar em LA, utilizando a LSF como teoria de microanálise dos dados; e (ii) investigação de representações do professor-colaborador do estágio supervisionado na escola básica, produzidas por aluno-mestre em relatório de estágio supervisionado obrigatório numa Licenciatura em Letras ${ }^{2}$. A realização do segundo objetivo de pesquisa exemplifica o percurso investigativo mencionado no primeiro. Subjacente a tais objetivos, está nosso esforço para caracterizar o que denominamos de escrita reflexiva profissional, concebida como um registro acadêmico aqui realizado no relatório de estágio, em função do empoderamento da formação do aluno-mestre ${ }^{3}$.

2. O professor-colaborador é o professor da escola básica que disponibiliza a própria sala de aula para o aluno-mestre observar e ministrar aulas. Esse profissional não tem vínculo formal com a universidade, apenas a rede pública estadual de ensino mantém um convênio que autoriza a realização dos estágios obrigatórios das licenciaturas nas escolas estaduais.

3. "Empoderamento é assim para Freire um processo que emerge das interações sociais em que nós, seres humanos, somo construídos e, à medida que, criticamente, problema- 
Este artigo está organizado em quatro principais seções, além da Introdução, Considerações finais e Referências bibliográficas. Em Documento e percurso investigativo, descrevemos os dados e os procedimentos metodológicos assumidos na pesquisa. Em Prática reflexiva do professor, caracterizamos a atividade de reflexão docente, a partir da literatura científica produzida em diferentes áreas do conhecimento, além de articular essa atividade ao conceito de letramento do professor. Em Escrita reflexiva a partir da LSF, caracterizamos a escrita reflexiva como um tipo de registro acadêmico produzido no contexto complexo do estágio obrigatório da licenciatura. Concomitante à caracterização, apresentamos brevemente uma síntese dos pressupostos teórico-metodológicos da LSF orientadores da microanálise linguística realizada. Finalmente, em Professor-colaborador na escrita reflexiva, apresentamos a análise do registro acadêmico investigado. Focalizamos algumas atitudes positivas e negativas sobre o professor-colaborador do estágio, identificadas nos relatórios, justificando a subdivisão da seção em Atitude positiva sobre o professor-colaborador e Atitude negativa sobre o professor-colaborador.

\section{Documentos e percurso investigativo}

Os dados investigados são relatórios de estágio supervisionado, produzidos por alunos-mestre da Licenciatura em Letras, habilitação em Língua Portuguesa, ofertada na Universidade Federal do Tocantins (UFT), Campus Universitário de Araguaína. Para este artigo, foram analisados 104 textos escolhidos aleatoriamente entre 636 relatórios produzidos nas disciplinas de Investigação da Prática Pedagógica e Estágio Supervisionado em Língua Portuguesa: Língua e Literatura I, II, III e IV, ministradas entre os anos de 2006 e $2012^{4}$.

Tais documentos fazem parte do acervo do Centro Interdisciplinar de Memória dos Estágios Supervisionados das Licenciaturas (CIMES),

tizamos a realidade, vamos nos "conscientizando", descobrindo brechas e ideologias; tal conscientização nos dá 'poder' para transformar as relações sociais de dominação, pode esse que leva à liberdade e à libertação" (Guareschi 2008: 166).

4. Para seleção dos dados, contamos com o trabalho realizado pela bolsista de iniciação científica Bárbara de Freitas Farah (2013). Somos gratos à bolsista pelo auxílio durante a produção deste artigo. 
onde estão arquivados os relatórios das Licenciaturas em Física, Geografia, Letras, Química e Matemática, todas pertencentes ao referido Campus. Tal centro foi criado no segundo semestre de 2009 e disponibiliza o acervo para consulta pela comunidade acadêmica. Atualmente, o centro vem se consolidando como um espaço de pesquisa para os alunos das licenciaturas, que consultam os relatórios arquivados para realização das atividades dos estágios obrigatórios.

A escolha dos textos produzidos a partir de 2006 se justifica pela consolidação da referida instituição como universidade pública federal, a exemplo do contexto em que, até então, estavam inseridas as disciplinas de estágio supervisionado da Licenciatura em Letras: eram ministradas por professores substitutos ou cedidos pelo governo estadual ${ }^{5}$. A partir do referido aluno letivo, professores efetivos começaram assumir a supervisão dos estágios, trazendo um maior respaldo teórico e, até mesmo, inovações para as referidas disciplinas e para as aulas ministradas pelo aluno-mestre na escola de educação básica.

Conforme investigação realizada por Silva e Melo (2008), em relatórios produzidos nos anos de 2004 e 2005, na licenciatura aqui focalizada, o gênero ainda estava bastante marcado pela escrita burocrática, pouco comprometida com a reflexão e a transformação das situações de ensino experienciadas nos estágios supervisionados obrigatórios. Quanto à data final de referência para a seleção dos dados, esclarecemos que, quando iniciamos esta pesquisa, não havia relatórios produzidos em 2013 disponíveis para investigação.

Sobre composição dos relatórios, salientamos que a estrutura esquemática dos textos é bastante diversificada, o que pode ser justificado, de acordo com Silva (2012a: 287), pela "falta de consenso entre os profissionais responsáveis por coordenar e ministrar os estágios supervisionados a respeito da operacionalização das orientações

5. O período entre 2003 e 2005 pode ser caracterizado como um momento marcado por transformação das práticas da antiga instituição estadual, Universidade do Tocantins (UNITINS). Parte dessa instituição foi federalizada a partir da criação da Universidade Federal do Tocantins (UFT) em 23 de outubro de 2000, sendo efetivadas as atividades da nova instituição a partir de maio de 2003, com a posse dos primeiros professores concursados da instituição. Maiores informações sobre essa fase de transição na gestão institucional, bem como sobre algumas transformações ocorridas nos estágios supervisionados, ver Melo (2011). 
oficiais sobre a disciplina". Os usos desses relatórios não podem cair no mesmo esvaziamento sofrido pela prática reflexiva na formação do professor, conforme discutido na próxima seção deste artigo. Os professores formadores, supervisores dos estágios obrigatórios, precisam ter consciência dos propósitos a serem atingidos com a escolha do gênero, bem como das estratégias didáticas mais produtivas para alcançá-los. Nos termos de Silva (2012b: 41):

o relatório não pode resultar num produto de uma atividade burocrática, cuja finalidade se reduz à atribuição de notas ou conceitos, quando o texto escrito produzido não encontra leitores interessados no conteúdo nele tematizado. Reduzido a instrumento de avaliação gerador de notas ou conceitos, o relatório se configura como um dos atores responsáveis pelo livre trânsito dos alunos-mestre pela licenciatura.

Para investigação dos relatórios, desenvolvemos uma análise essencialmente qualitativa dos dados, ancorada em pressupostos teóricos da LSF, especialmente nas noções de contexto de cultura e de metafunções da linguagem, as quais são representativas da abordagem funcionalista da linguagem assumida. De acordo com Halliday (2003[1973]), as opções comportamentais dos participantes das atividades sociais são realizadas através da língua e influenciadas pelo contexto em que estão inseridos. Os participantes também influenciam o contexto, as relações instauradas entre os primeiros e esse último são de mútua interferência. Nas palavras do autor, "a partir de uma interpretação funcional do sistema semântico, nós podemos começar a apreciar como a língua, simultaneamente, expressa sentidos particulares a determinados contextos de situação, e serve para transmitir padrões essenciais de orientação no contexto total de cultura" (Halliday 2003 [1973]: 365).

Para caracterização do contexto da prática de escrita reflexiva na formação do aluno-mestre, ensaiamos uma releitura da noção teórica de contexto de cultura a partir do percurso investigativo transdisciplinar da LA. O contexto acadêmico focalizado foi caracterizado pela revisão da literatura científica produzida em diferentes áreas do conhecimento, sobre a relevância da prática de reflexão docente. A caracterização desse contexto serviu de parâmetro para a análise linguística das represen-

6. Neste artigo, somos responsáveis pelas traduções de todas as citações cujos originais estão escritos em língua inglesa. 
tações do professor-colaborador, construídas pelo aluno-mestre nos relatórios de estágio, bem como para a identificação de características da escrita reflexiva profissional. As metafunções da linguagem orientaram a análise linguística, realizada pelo enfoque de realizações gramaticais que julgamos responsáveis pelas representações identificadas.

As noções de forma e função orientaram o percurso investigativo para a microanálise dos dados trilhado na pesquisa. A observação dos relatórios de estágio, a partir da LSF como teoria linguística de referência, resultou na identificação de formas gramaticais regulares responsáveis pela textualização de discursos sobre o professor-colaborador. Conforme esclarecemos adiante, esses discursos revelam funções sociais exercidas pelas formas gramaticais no contexto institucional do estágio da licenciatura. De acordo com Halliday (2003[1973]: 363), "a função social da língua é central para a interpretação da língua como sistema. A organização interna da língua não é acidental, ela incorpora as funções que a língua evolveu para servir na vida do homem social".

Esse percurso de análise configura a abordagem funcionalista de representações sociais desenvolvida na pesquisa. Conforme discutido adiante, essas representações estão ancoradas na concepção de cultura assumida a partir de Malinowski (2012), antropólogo que influenciou bastante os pressupostos teórico-metodológicos na LSF. De acordo com o autor,

como um trabalho manual do homem e como meio através do qual ele alcança seus objetivos - um meio que o permite viver, estabelecer um padrão de segurança, conforto e prosperidade; um meio que lhe proporciona força e lhe permite criar bens e valores além de sua condição animal e orgânica - a cultura, em tudo isto e através disto tudo, deve ser compreendida como um recurso para um fim, o que é, instrumental e funcional. (Malinowski 2012: 67)

Finalmente, para exemplificação das representações de professorcolaborador, escolhemos parágrafos dos relatórios considerados representativos das ocorrências identificadas durante a leitura analítica dos documentos selecionados. Os exemplos estão identificados parcialmente pelo período, ano e semestre letivos em que o estágio foi ministrado, além da identificação da série e nível de ensino em que 
o aluno-mestre realizou o estágio obrigatório ( $8^{\circ}$ período, 2006.1, $1^{\circ}$ Ano - Ensino Médio).

\section{Prática reflexiva do professor}

Não há dúvida de que o professor - em formação inicial ou em serviço -, assim como qualquer outro profissional, faz alguma reflexão sobre atividades desempenhadas no local de trabalho. Dito isso, questionamo-nos a respeito das especificidades trazidas pelos itens lexicais reflexão ou reflexivo quando utilizados, em contextos de instrução formal, em referência a práticas profissionais desejadas para os professores no local de trabalho (Schön 1983). Essas práticas correspondem à reflexão ou ao diálogo com o próprio eu (self) na/sobre as situações de ensino instauradas no espaço de atuação profissional. Podem ser motivadas a partir da colaboração de outros interactantes, resultando no compartilhamento de saberes em prol do empoderamento profissional coletivo.

No âmbito da Educação, retomando os estudos desenvolvidos por Schön (1983), Perrenoud (2002: 30 e 31) faz referência a dois processos mentais complementares para caracterizar o que autor compreende por prática reflexiva no exercício da docência, as quais são descritas no Quadro 1.

\section{Quadro 1 - Tipos de Reflexão}

\begin{tabular}{|c|l|}
\hline REFLEXÃO & $\begin{array}{l}\text { "tomamos nossa própria ação como objeto de reflexão, seja para } \\
\text { compará-la com um modelo prescritivo, o que poderíamos ou } \\
\text { deveríamos ter feito, o que outro profissional teria feito, seja para } \\
\text { explicá-la ou criticá-la" (itálico do original). }\end{array}$ \\
\hline REFLEXÃO AÇÃO & $\begin{array}{l}\text { "consiste em se perguntar o que está acontecendo ou o que vai } \\
\text { acontecer, o que podemos fazer, o que devemos fazer, qual é a } \\
\text { melhor tática, que desvios e precauções temos de tomar, que } \\
\text { riscos corremos, etc". }\end{array}$ \\
\hline
\end{tabular}

O relatório de estágio funciona como um instrumento de mediação desencadeador da "reflexão sobre a ação", ou seja, especialmente sobre as aulas ministradas pelo professor-colaborador, quando o aluno mestre apenas observa o trabalho docente, ou sobre as próprias aulas ministra- 
das, quando o aluno-mestre assume atividades de ensino na turma em que, previamente, observou aulas. A familiarização do aluno-mestre com esse primeiro tipo de reflexão pode resultar numa consciência crítica para a "reflexão na ação", quando o professor analisa o próprio trabalho realizado no calor das atividades em curso.

O esforço na instrução de professores familiarizados com essas práticas informa pesquisas realizadas em disciplinas que se propõem a focalizar a formação docente, a exemplo das propostas apresentadas por Perrenoud (2002) e Edge (2011), no âmbito da Educação e LA, respectivamente. Ao tematizar a reflexão sobre a ação, tais autores se utilizam das subcategorias reflexão "retrospectiva" e "prospectiva" para caracterizar a prática tematizada (ver Quadro 2). Apesar de compartilharem nomenclaturas idênticas, as concepções apresentadas pelos autores são diferentes, ainda que sejam complementares. Para o primeiro, o momento de realização da reflexão - antes ou após a atividade profissional - determina o tipo de reflexão, ao passo que, para o segundo, o elemento determinante é a agência assumida no local de trabalho - trabalho ou pessoa como agente de ações desencadeadas.

Quadro 2 - Tipos de Reflexão sobre a Ação

\begin{tabular}{|l|l|}
\hline Perrenoud (2002: 36) & Edge (2011:38) \\
\hline \multicolumn{2}{|c|}{ RETROSPECTIVA } \\
\hline $\begin{array}{l}\text { "subsequente a uma atividade ou a uma interação, } \\
\text { ou a um momento de calmaria. Sua função principal } \\
\text { é ajudar a fazer um balanço, a compreender o que } \\
\text { deu ou não certo e a preparar o profissional caso a } \\
\text { ação se repita". }\end{array}$ & $\begin{array}{l}\text { Pessoa". } \\
\text { PROSPECTIVA do trabalho sobre a }\end{array}$ \\
\hline $\begin{array}{l}|c| \\
\text { "ocorre no momento do planejamento de uma nova } \\
\text { atividade ou da antecipação de um acontecimento } \\
\text { ou de um problema novo". }\end{array}$ & $\begin{array}{l}\text { "quando fala especificamente } \\
\text { sobre o efeito da pessoa sobre o } \\
\text { trabalho". }\end{array}$ \\
\hline
\end{tabular}

Os benefícios advindos do ensino reflexivo na formação docente não encobrem possíveis práticas que possam minar "o potencial para o desenvolvimento real dos professores", a exemplo de ênfases em atividades individualistas de reflexão sobre o trabalho docente em função da reprodução de uma ordem estabelecida. Ou seja, a reflexão deve ser realizada para transformar a prática profissional e não, simplesmente, para confirmar ou consolidar as atividades costumeiras, ignorando-se o 
contexto institucional mais amplo, bem como percursos metodológicos alternativos (ZEICHNER 2008: 542) 7 . Distorções da concepção de ensino reflexivo se confundem com o desgaste sofrido pela proposta original no âmbito da Educação, proposta ainda na década de 80 do século passado por Schön (1983). Conforme esclarecido por Zeichner (2008: 538), o ensino reflexivo "começou a perder qualquer significado específico", após se tornar "rapidamente um slogan adotado por formadores de educadores das mais diferentes perspectivas políticas e ideológicas para justificar o que faziam em seus programas" (itálico do original).

Tal desgaste sofrido pelo rótulo ensino reflexivo não minimizou a relevância dessa prática na formação docente. No âmbito da formação de professores em serviço, por exemplo, mencionamos o programa de ensino reflexivo de professores de língua inglesa, envolvendo instituições de ensino básico e superior, nas redes pública e privada de ensino do Estado de São Paulo, conforme descrito em Magalhães e Celani (2005) e Liberali (2004). Do ponto de vista da pesquisa científica, foi investigado como os professores de inglês da rede pública paulista poderiam ser educados numa perspectiva reflexiva e crítica sobre suas atividades profissionais. Do ponto de vista do ensino de língua, esforços foram despendidos para formar professores críticos a partir da prática reflexiva colaborativa com a qual se familiarizaram, além de torná-los multiplicadores dessa prática no local de trabalho.

No estágio supervisionado obrigatório da licenciatura, contexto institucional focalizado neste artigo, a relevância do ensino reflexivo se justifica pela demanda de autonomia exigida do aluno-mestre especialmente no espaço escolar, uma vez que a licenciatura, enquanto principal agência desencadeadora do letramento do professor, não prevê as infindáveis situações de ensino com as quais o professor se deparará no exercício da profissão. Conforme orientam Grant e Zeichner (1984: 108), o aluno-mestre "pode inteligentemente aplicar o conhecimento e habilidades adquiridos na preparação formal para o magistério em situações que podem ser muito diferentes das experienciadas durante esse período de formação inicial". Nessa perspectiva, ainda nas pala-

7. Ainda segundo Zeichner (2008: 541), essa distorção do sentido do ensino reflexivo criou "uma ilusão do desenvolvimento docente que manteve, de maneiras mais sutis, a posição de subserviência do professor". 
vras dos autores, "tornar-se um professor reflexivo é um processo de crescimento contínuo" (Grant e Zeichner 1984: 111).

Em nosso percurso investigativo transdisciplinar, relacionamos a proposta de "formação reflexiva docente", no termo utilizado por Zeichner (2008: 545), aos estudos do "letramento do professor", tomando como principais referenciais teóricos alguns estudos produzidos por Kleiman $(2009 ; 2008)$ em resposta a situações de "desprestígio e desvalorização" dos profissionais do magistério, compreendendo "um crescente empobrecimento das (auto)representações do professor sobre sua capacidade profissional" (Kleiman 2009: 19). Ainda segundo a autora, compreendemos

o letramento do professor não como mero instrumento para realização do trabalho, mas como aspecto constitutivo, identitário de sua função como formador de novos leitores e usuários da língua escrita, ou seja, intrinsecamente ligado a sua atuação profissional (Kleiman 2009: 21).

Nessa perspectiva, compartilhamos do posicionamento político e revolucionário assumido por Zeichner (2008: 545) sobre a "formação reflexiva docente", e por tantos outros educadores, como o brasileiro Paulo Freire (1987). Esse posicionamento deve estar "conectada a lutas mais amplas por justiça social e contribuir para a diminuição das lacunas na qualidade da educação disponível para estudantes de diferentes perfis" (Zeichner 2008: 545) ${ }^{8}$. Tal luta também deve estar orientada a favor da própria identidade do professor, sendo a escrita reflexiva profissional um instrumento de mediação favorável ao fortalecimento do letramento do aluno-mestre, envolvendo usos da escrita nos domínios acadêmico e profissional/escolar.

A título de exemplo, ressaltamos o estudo produzido por Fiad e Silva (2009: 123), ao investigarem a relevância do uso do que denominamos aqui de escrita reflexiva profissional em disciplinas curriculares

8. Ainda segundo Zeichner (2008: 539), "quando adotamos o conceito de ensino reflexivo, existe em geral um compromisso dos formadores de educadores em ajudar futuros professores a internalizarem, durante sua preparação inicial, as disposições e as habilidades para aprender a partir de suas experiências e tornarem-se melhores naquilo que fazem ao longo de suas carreiras docentes". 
das licenciaturas brasileiras, a qual se configura em gêneros textuais como "relato, memorial e carta". Nos termos das autoras,

nos cursos de formação de professores, especialmente, essa forma de expressão passou a ser bastante explorada, como caminho de valorização dos saberes docentes, construção das identidades profissionais, das relações entre ensinar e aprender, entre formador e docente em formação, entre teoria e prática, entre ação e reflexão.

Nessa perspectiva, a fim de familiarizar professores com práticas reflexivas de ensino, educadores se utilizam de estratégias didáticas diversas, sobre as quais inúmeros pesquisadores também se debruçam para estudo. No programa de ensino reflexivo de professores de língua inglesa, a que fizemos referência previamente a partir de Magalhães e Celani (2005) e Liberali (2004), por exemplo, foram utilizadas especialmente sessões reflexivas para desencadear a aprendizagem colaborativa entre duplas de professores que discutem as próprias práticas profissionais ou as de um terceiro professor, a partir de registros de aulas em vídeo ou de relatos reflexivos produzidos ${ }^{9}$.

No contexto do estágio supervisionado da licenciatura, Zeichner (2008: 542) faz referência a exemplos em vários países onde estratégias ou esforços foram despendidos por "formadores de educadores para encorajar a reflexão de seus estudantes", como o estudo apresentado por Feiman-Nemser e Beasley (2007) a partir de um experimento envolvendo uma escola de educação básica vinculada à Michigan State University. Em função do empoderamento dos atores envolvidos nos estágios, as autoras relatam como foram criados novos papéis para o supervisor e o professor-colaborador do estágio, além de como foram criados fóruns onde tal professor criou novas maneiras de pensar e de trabalhar com o aluno-mestre. Essa experiência desencadeou a prática reflexiva desses três principais atores do estágio supervisionado.

9. De acordo com Magalhães e Celani (2005: 142), “a sessão reflexiva era para ser um local de investigação colaborativa de formas conflitivas dos participantes avaliarem e representarem suas próprias formas de agir, suas intenções e motivos para agir de uma forma ou outra, num contexto escolar específico. Ela possibilitaria aos professores compreenderem as representações de cada participante sobre conceitos de ensino, organização de prática discursiva de sala de aula, questionamento discursivo prático de sala de aula e novas maneiras de saber, de agir e de negociar". 
Na seção seguinte, apresentamos uma caracterização inicial da escrita reflexiva profissional, realizada em relatórios de estágio supervisionado. Concebida como um registro particular da escrita acadêmica, a reflexiva profissional se configura como uma estratégia didática que pode desencadear o ensino crítico no contexto da formação inicial de professores, contribuindo para o letramento do aluno-mestre. Tal caracterização é realizada a partir dos pressupostos teóricos da LSF.

\section{Escrita reflexiva a partir da LSF}

A escrita de alunos universitários tem sido alvo de inúmeras investigações científicas na LA (Fiad 2011; Fiad e Silva 2009; Hewings e North 2006; Melo, Conçalves e Silva 2013; Ninin e Barbara 2013; Silva 2013; 2012a; 2012b; Silva e Pereira 2013; Silva, Santos e Mendes, 2014), o que pode ser justificado pelo fato da "produção textual de estudantes de graduação" pressupor "uma importante transição nos modos de escrita vivenciados no ensino básico, por exigir dos autores capacidades analíticas e maior compreensão de análise crítica e argumentação" (Ninin e Barbara 2013: 128; itálico nosso).

No campo dos estudos do letramento, as investigações sobre a escrita acadêmica são produzidas em resposta ao "discurso da crise", no termo utilizado por Fiad (2011: 360) ao fazer referência à crença propagada na universidade a respeito dos alunos ingressantes no contexto acadêmico, os quais, por serem originários de escolas ditas "fracassadas", são vistos como iletrados, pois seus letramentos não são reconhecidos pela instituição. Os estudos mencionados mostram que, na realidade, tais alunos são "sujeitos letrados e iniciantes em práticas letradas até então desconhecidas" (Fiad 2011: 361), ou seja, apenas "não se engajaram ainda nas práticas letradas esperadas no contexto acadêmico" (Fiad 2011: 360).

Além do letramento acadêmico mencionado, a demanda pela instrução do professor reflexivo, autônomo para analisar criticamente sua própria prática profissional, é outro desafio posto na formação inicial do professor. Esses desafios parecem motivar a produção da escrita reflexiva profissional no contexto da licenciatura. Essa escrita se configura como uma realização particularizada do registro acadêmico 
convenciona $1^{10}$. Nos relatórios de estágio supervisionado, ela pode proporcionar maior liberdade para o aluno-mestre relatar experiências e posicionar-se criticamente diante das aulas observadas ou ministradas na escola de ensino básico. Em outras palavras, o aluno-mestre estaria menos preso às formalidades da escrita acadêmica convencional.

Reproduzimos adiante dois excertos representativos do que se tem compreendido na literatura científica por escrita reflexiva. Numa perspectiva ampla, mais distanciada do contexto de formação do professor, encontramos uma concepção desse registro proposta no campo de estudo da Escrita Criativa. Na Linguística Aplicada, encontramos uma concepção produzida a partir do próprio estágio supervisionado da licenciatura. A justaposição das concepções ajuda-nos a compreender esse registro renovado da escrita acadêmica focalizada.

\section{ESCRITA CRIATIVA}

Reflexão é um processo diferente e potencialmente profundo. Em seu centro, há um tipo particular de 'engajamento com um outro', ou uma outra pessoa ou um eu mesmo como 'outro'. Onde reflexão pode envolver alguma coisa dentro de um eu mesmo - um tópico, um evento, uma relação - para o propósito de contemplação ou exame, reflexão envolve colocar algo para fora com propósito de algo novo vir a ser. Isso envolve criar um espaço interno, distanciando nós mesmos de nós mesmos, como se isso fosse. Então nós somos simultaneamente ambos 'dentro' e 'fora' de nós mesmos e capazes de voltar e seguir fluidamente e brincando de uma posição para outra, dando a nós mesmo a experiência de "eu como outro" enquanto também retém uma base em nosso senso familiar de si mesmo (Hunt e Sampson, 2006: 4).

\section{LINGUÍSTICA APLICADA}

[na escrita reflexiva] o estudante passa a ser o grande elemento de referência para o seu dizer. É 'obrigado' a voltar-se, em alguma medida, para si mesmo, não fazendo apenas do outro - uma voz já reconhecida e autorizada, academicamente falando - sua maior referência, muito embora possa com ela dialogar o tempo todo. Nessa perspectiva é que determinados gêneros de discurso passam a ser mais estimulados, pois se entende que eles podem melhor acolher essa voz. (Fiad e Silva 2009: 124)

10. Concebemos "registro ou repertório linguístico de uma comunidade ou de um indivíduo como derivado da variedade de usos que a língua realiza numa cultura particular ou subcultura" (Halliday 2003[1973]: 343). 
A partir das concepções reproduzidas, a escrita reflexiva profissional pode ser concebida como a materialização do diálogo entre o aluno-mestre, responsável pela produção do registro escrito, com o próprio eu distanciado e, até mesmo, mais indiretamente, com os demais atores sociais envolvidos nos estágios obrigatórios, como supervisor, professor-colaborador, aluno da escola básica e outros alunos-mestre, além das literaturas científicas e não científicas mobilizadas para a construção textual, muitas vezes, como fontes de "modelos prescritivos" (Perrenoud 2002: 31) ${ }^{11}$. Essa trama é realizada em função da (re) construção colaborativa de saberes orientadores da prática profissional do professor em formação.

A familiarização do aluno-mestre com a reflexão crítica sobre a própria atuação profissional, provavelmente, não seja a única justificativa para o uso do registro aqui focalizado na formação inicial do professor. Outra justificativa seria a difícil apropriação por esse aluno das convenções da escrita acadêmica tradicional, conforme observamos na investigação de trabalhos de conclusão de curso (TCC), realizada por Ninin e Barbara (2013). À luz do subsistema de engajamento, disponível na teoria da avaliatividade da LSF, as autoras investigaram como graduandos em Letras fazem citações de autores usados como referência nos TCC, considerando os posicionamentos por eles assumidos diante das citações. Os resultados da pesquisa mostram que:

o aluno da graduação marca uma posição de pouca responsabilidade em relação às proposições convidadas ao texto, contrariando o que se tem como meta no ensino superior - o desenvolvimento e a autonomia intelectual do aluno. Embora este tenha contato contínuo, ao longo da graduação, com a escrita acadêmica e leia textos científicos, não demonstra ter internalizado suas características linguístico-discursivas (Ninin e Barbara 2013: 142).

Tais desafios na instrução do aluno-mestre, aqui reconstruídos a partir do diálogo entre disciplinas, auxiliam-nos na descrição do contexto em que a escrita reflexiva profissional está inserida, o que

11. A função dessas literaturas na escrita reflexiva profissional ainda precisa ser investigada, haja vista que o registro reflexivo parece ser proposto em contraposição ao acadêmico convencional, quando a literatura científica desempenha função de autoridade conhecida no domínio acadêmico (Melo 2014; Melo, Gonçalves e Silva 2013). 
contribui para a microanálise proposta de algumas representações do professor-colaborador do estágio. Essa análise é orientada pela LSF, abordagem teórica em que, por sua natureza sociossemiótica, "a língua é compreendida em sua relação com as estruturas sociais", as quais são instauradas nas relações humanas configuradoras do contexto de cultura (Halliday 1989: 4). Nessa perspectiva, a investigação da escrita dos relatórios pode lançar luz sobre relações sociais instauradas entre as instituições de ensino envolvidas no estágio, bem como entre os participantes: aluno-mestre, professor-colaborador, supervisor, aluno, dentre outros atores sociais representantes das instituições mencionadas.

Em seu sentido amplo, uma vez que é desdobrado em de situação e de cultura, o contexto se revela por meio da língua ou das mais diferentes manifestações da linguagem. As escolhas léxico-gramaticais, realizadas pelos usuários em sistemas gramaticais da língua portuguesa para a produção dos relatórios de estágio investigados, ou, até mesmo, a escolha da disposição das seções integrantes da estrutura esquemática do referido gênero, são exemplos de motivações culturais, as quais são construídas nas/além das práticas acadêmicas da licenciatura focalizada (Pereira, 2014; Silva 2013, 2012a, 2012b; Silva e Fajardo-Turbin 2012; Silva e Mendes 2012).

Sintetizamos essa relação entre língua e contexto social na Figura 1, na qual apresentamos uma adaptação da representação das categorias de sistema, instância, contexto e língua, articuladas pelas relações de realização e instanciação, conforme Hasan (2009: 169). Neste artigo, não temos a intenção de apresentar uma revisão detalhada dos pressupostos teórico-metodológicos da LSF. Maiores detalhes sobre a teoria podem ser encontrados em Eggins (2004), Halliday (2003 [1973],

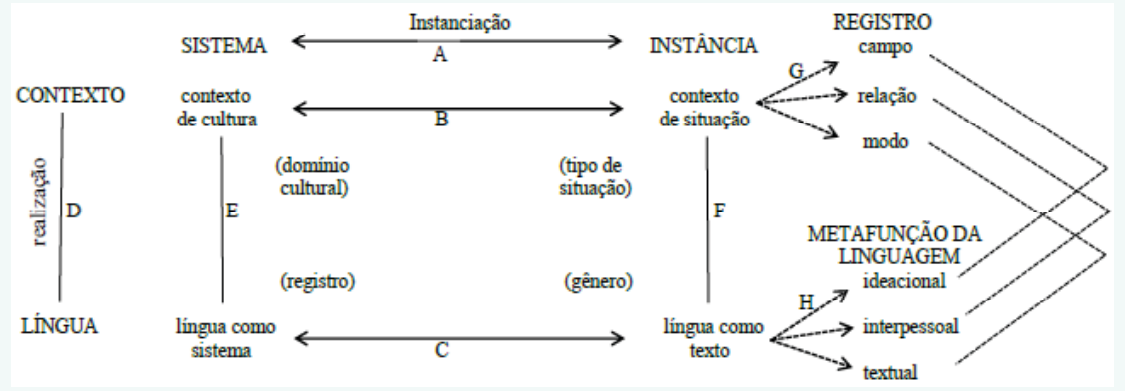

Figura 1 - Relação entre língua e contexto: sistema e instância. 
1985), Halliday e Matthiessen (2014, 1999), Hasan (2009, 2003 [1973], 1985), Matthiessen e Halliday (2009), Matthiessen, Teruya e Lam (2010), Silva e Espindola (2014, 2013) e Thompson (2014).

As setas posicionadas horizontalmente representam a relação de instanciação, caracterizada por possibilidades de escolhas feitas dentro do sistema. A instância é uma possibilidade selecionada dentro das regularidades disponibilizadas no sistema. Nessa perspectiva, a seta $A$ representa o sistema como um repositório de possibilidades de instâncias. O sistema é constituído por alternativas de usos regulares de formas linguísticas disponíveis e reconhecíveis socialmente. Nas palavras de Hasan (2009: 169), a instância "é o que é imediato e experienciado", ao passo que o sistema "é o ponto final da teorização do que é experienciado e imaginável por extrapolação". O sistema é um "conjunto de opções reconhecíveis empiricamente na gramática, corresponde ao poucos domínios altamente generalizáveis de sentido, os quais são essenciais para o funcionamento social da linguagem" (Halliday 2003[1973]: 363).

A seta $B$ representa o contexto de cultura como possibilidades de práticas sociais, ao passo que o de situação é uma instância das possibilidades inerentes ao primeiro mencionado. Podemos caracterizar o relatório de estágio, por exemplo, como uma instância de práticas acadêmicas, apropriada pelos formadores da licenciatura para que o aluno-mestre demonstre o conhecimento adquirido durante o estágio supervisionado obrigatório. No domínio acadêmico, há outros gêneros discursivos circulando como dispositivos avaliativos dos graduandos, como o artigo científico e o TCC, porém, por razões discutidas previamente neste artigo, o relatório de estágio se configura como principal modelo textual para realização da escrita reflexiva profissional. Nos termos de Motta-Roth (2011: 153), o gênero é um "fenômeno estruturador da cultura". Conforme representado na seta $C$, o gênero ou a língua como texto corresponde a uma instância configurada a partir de possibilidades de organização da língua como sistema ${ }^{12}$.

12. Nesse ponto, nossa representação da relação entre língua e contexto se diferencia da figura apresentada por Hasan (2009: 169). A autora utiliza a denominação tipo de texto em detrimento da noção de gênero discursivo utilizada neste artigo. 
Ainda explicando a Figura 1, as retas verticais, por sua vez, representam relações de realização, as quais são responsáveis pela configuração semiótica da linguagem em estratos, a exemplo da mútua influência entre escolhas léxico-gramaticais e práticas contextuais, resultando na produção de sentidos num estrato semântico intermediário, localizado entre os estratos das duas escolhas citadas. Dada a relação de instanciação representada na seta $B$, o contexto de cultura está situado num estrato acima do contexto de situação, ademais esse último é tomado como uma instância das possibilidades inerentes ao primeiro contexto mencionado.

Nesta pesquisa, focalizamos o contexto de cultura pela noção teórica de gênero, conforme proposta por Motta-Roth (2011: 157) ao discutir perspectivas de ensino e pesquisa de "gêneros pela observação da relação estreita entre texto e contexto". De acordo com a autora, os gêneros são "atividades culturalmente pertinentes, mediadas pela linguagem num dado contexto de situação, atravessado por discursos de ordens diversas" (Motta-Roth 2011: 157). São construídos nas interações sociais orientadas por práticas culturais funcionalmente motivadas, as quais estão sujeitas a constantes transformações. Essas práticas estão envolvidas em discursos, ou seja, produzem representações das coisas no mundo, são passíveis de análise a partir da materialidade textual.

A noção de cultura é esclarecedora para a compreensão dessas formas estabilizadas de uso da língua, as quais foram denominadas por Halliday (2003 [1973]: 346-347) de "contextos generalizados", "tipos de situação" e, até mesmo, "rotinas do dia de trabalho". Conforme Malinowski (2012: 119), antropólogo responsável pelo conceito teórico de contexto de cultura apropriado na LSF,

a cultura supre o homem com potencialidades, habilidades e forças derivadas. Isso também significa que a enorme extensão no alcance da ação humana, para além das habilidades inatas do organismo nu, impõe ao homem um número de limitações. Em outras palavras, cultura impõe um novo tipo de determinismo específico ao comportamento humano.

Ainda na primeira metade do século passado, ao tematizar algumas contribuições da antropologia para diferentes disciplinas do conhecimento, propondo a interação entre disciplinas nas ciências humanas, 
a partir do conceito de cultura, Malinowski (2012: 5) afirma que "a cultura, como mais vasto contexto do comportamento humano, é tão importante para o psicólogo quanto para o sociólogo estudante, para o historiador tanto quanto para o linguista". O autor garante, veementemente, que "a linguística do futuro, especialmente no que diz respeito à ciência do significado, tornar-se-á o estudo da língua no contexto de cultura" (itálico nosso).

Mesmo não utilizando a nomenclatura gênero, as palavras de Halliday (2003 [1973]: 347) são esclarecedoras sobre algumas contribuições práticas trazidas por tal noção teórica. Segundo o autor, "quando falamos de 'funções sociais' da linguagem", inevitavelmente, referimo-nos a formas estabilizadas características de contextos situacionais. Também "somos capazes identificar sentidos potenciais característicos desses contextos". Ao procedermos dessa maneira, ainda conforme o autor, "podemos jogar luz sobre certos traços na organização interna da língua".

Essa relação funcional entre contextos e formas linguísticas aponta para a metarredundância estabelecida entre as noções de registro e as de metafunções da linguagem, representadas em $G$ e $H$ na Figura 1, pelas setas e retas tracejadas ${ }^{13}$. Nos termos de Halliday (1985: 12), o registro é uma configuração semântica expressa pelas variáveis de campo de discurso ("o que está acontecendo"), relação de discurso ("quem está participando") e modo de discurso ("qual o papel está sendo exercido pela língua"). Tais variações correspondem, respectivamente, nos termos de Thompson (2014: 30), às metafunções ideacional ("usando língua para enunciar sobre o mundo"), interpessoal ("usando a língua para interagir com outra pessoa") e textual ("organizando a língua para se ajustar ao contexto de uso").

As metafunções são caracterizadas por Halliday (2003 [1973]: 356) como "manifestações linguísticas altamente abstratas da multiplicidade de usos sociais da linguagem", pois são concebidas pelo autor como "macrofunções" desencadeadoras de inúmeras outras funções sociais da linguagem, consequentemente, responsáveis pela produção de sentidos diversos. Essas outras funções são denominadas pelo autor de "funções básicas, as quais são servidas pela língua”. As três metafunções men-

13. Na Figura 1, essa representação da metarredundância na LSF também diferencia nossa representação da apresentada por Hasan (2009: 169). 
cionadas são realizadas, respectivamente, nos sistemas linguísticos de TRANSITIVIDADE, MODO e TEMA.

Finalizando nossas considerações em torno da reciprocidade entre a escrita reflexiva profissional e a licenciatura, em termos teóricos, entre texto e contexto na perspectiva sistêmico-funcional aqui assumida, apresentamos na Figura 2 uma tentativa de esboço do complexo contexto em que está inserido o estágio supervisionado. Concebemos essa disciplina como uma instituição onde a escrita reflexiva profissional é produzida. De acordo com Malinowski (2012; 39), o conceito de instituição

implica um acordo a respeito de um conjunto de valores tradicionais para os quais os seres humanos se agrupam. Também implica em esses seres humanos se posicionarem em relação definida um para o outro e para uma específica parte física dos seus ambientes, natural e artificial. (...) seres humanos agem juntos e, assim, satisfazem alguns dos seus desejos, enquanto também produzem uma impressão no seu ambiente.

A complexidade contextual é justificada pelas interações estabelecidas entre os participantes que podem transitar entre as quatro instituições representadas na Figura 2 por círculos sobrepostos com bordas pontilhadas - escola, estágio supervisionado, licenciatura e universidade. Essas bordas representam fronteiras tênues ou fluidas entre instituições.

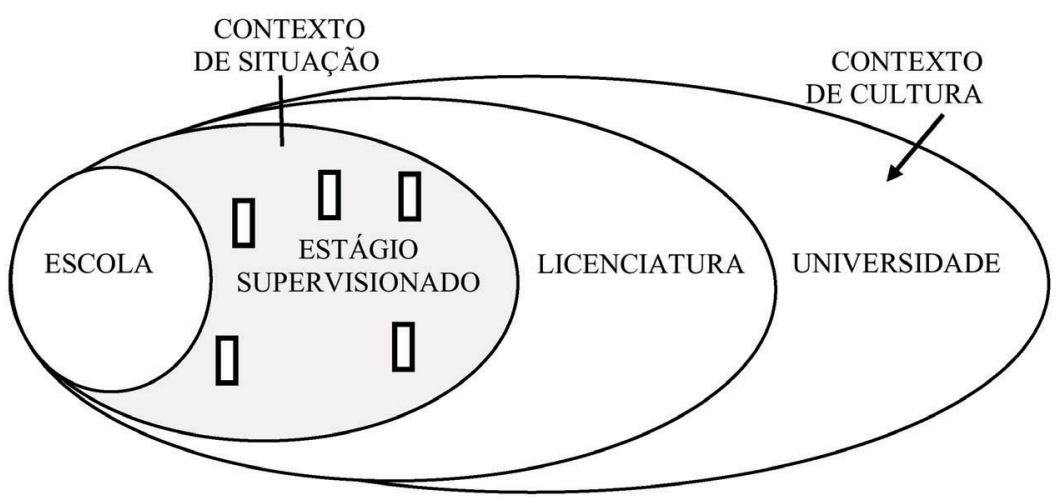

Figura 2 - Contexto Complexo do Estágio Supervisionado ${ }^{14}$. 
Delimitar o alcance do contexto de cultura, provavelmente, seja uma tarefa pouco relevante devido à imprecisão dos seus limites. Porém, para fins metodológicos, assumimos aqui o estágio supervisionado como o contexto de situação focalizado, e consideramos a universidade como o contexto de cultura de referência, dada a relevância e a abrangência das práticas sociais produzidas nessa instituição para as atividades da disciplina acadêmica, a exemplo do uso da escrita reflexiva profissional na formação inicial do professor. As diferentes licenciaturas também são responsáveis por práticas sociais características na universidade. A escola de educação básica precisa ser considerada na investigação dos estágios supervisionados, é uma instituição componente desse contexto cultural de difícil mapeamento.

Para fins investigativos, acreditamos que a delimitação dos contextos de cultura e de situação esteja condicionada aos objetivos de pesquisa. Representado na Figura 2 por retângulos, cada relatório de estágio traz semiotizado em sua materialidade textual diferente campo, relação e modo de discurso, os quais são instaurados nas práticas sociais características de cada disciplina. No entanto, o volume dos dados investigados neste artigo nos permite ampliar o foco do contexto de situação, delimitado pela seleção dos relatórios produzidos nos estágios da Licenciatura em Letras, assim como o foco do contexto de cultura, conforme descrito no parágrafo anterior. Nessa perspectiva, a investigação da escrita reflexiva profissional se configura como uma caracterização de um registro particularizado da escrita produzida na academia.

\section{Professor-colaborador na escrita reflexiva}

Dentro da pesquisa aqui focalizada, Silva e Espindola (2014) desenvolveram previamente um sistema de discursos sobre o professorcolaborador do estágio a partir de representações desse ator social na função de sujeito da oração ${ }^{15}$. Para produção do sistema, foi dada ênfase à função ideacional da linguagem, quando foram enfatizadas as funções

15. De acordo com Silva e Pereira (2013: 3), "por atores sociais, compreendemos atores humanos ou não humanos responsáveis pelo desencadeamento de ações em diferentes domínios institucionais, tais atores também recebem ações em semelhante proporção. Desempenham papeis nas práticas construídas socialmente e são representados textualmente a partir da seleção léxico-gramatical no sistema linguístico de referência”. 
de participante e de processo na oração ${ }^{16}$. Conforme sintetizado na Figura 3, o professor-colaborador pode ser representado como agente (orações material, verbal e mental) ou caracterizado/descrito de alguma forma (processo relacional). Na primeira possibilidade, o professorcolaborador pode ser um agente autônomo do processo criado por ele mesmo, estando explicitamente ou não presente na oração, ou ainda um agente não autônomo de um processo proposto por outro participante, que, por sua vez, pode ser o aluno-mestre ou algum agente legal, como um livro didático ou uma diretriz curricular. Na segunda possibilidade, o professor-colaborador pode ser caracterizado por outro participante, estando explícito ou não na oração, ou pode ser autocaracterizado.

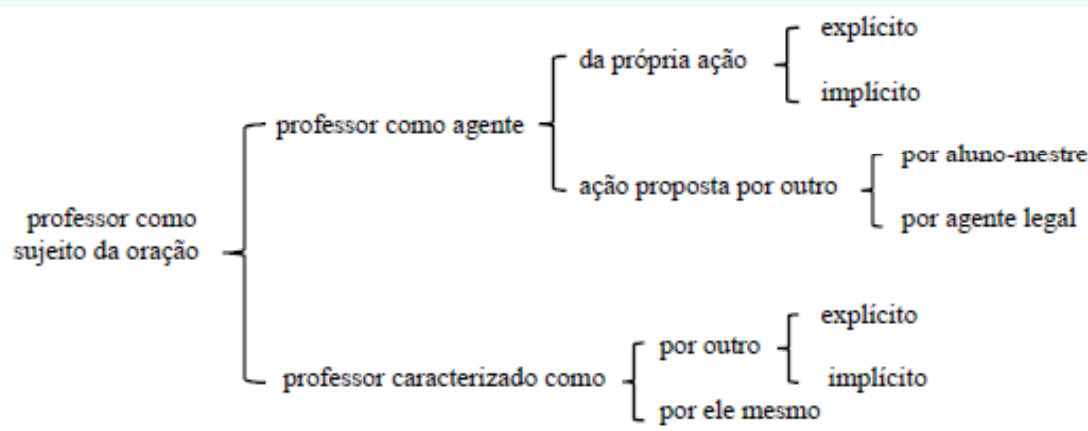

Figura 3 - Sistema Discursivo. Representação do Professor-Colaborador como Sujeito da Oração.

Neste artigo, tomamos o sistema discursivo representado na Figura 3 como referência e registramos outras representações construídas na escrita reflexiva profissional. Ainda não temos ocorrências suficientes para elaborarmos novos sistemas discursivos, mas realizamos uma leitura crítica dos dados tomando como referência, simultaneamente, as três metafunções da linguagem mencionadas na seção anterior. Cada metafunção pôde ser focalizada a partir de realizações gramaticais sobresselentes nas orações, afinal, conforme destaca Halliday (2003 [1973]: 363), uma oração

16. De acordo com Halliday (2003 [1973]: 359), “a oração é uma unidade estrutural pela qual nós expressamos uma variedade particular de sentidos ideacionais, nossa experiência de processos - o processo de consciência, visão, ligação, pensamento, fala e outros. Transitividade é simplesmente a gramática da oração no seu aspecto ideacional”. 
é simultaneamente realização de significados ideacional, interpessoal e textual. Mas estes componentes não são postos juntos num estilo discreto de tal forma que nós possamos apontar para um segmento da oração como responsável por expressar um tipo de sentido e outro segmento por expressar outro sentido. A escolha de uma palavra pode expressar um tipo de sentido, sua morfologia outro, e sua posição na sequência outro. E qualquer elemento é provável que tenha mais de um papel estrutural, como um acorde em uma estrutura polifônica que participa simultaneamente em inúmeras linhas melódicas.

Mesmo utilizando as três metafunções da linguagem nas subseções seguintes, a interpessoal sobressaiu nas análises dos relatórios, pois, ao direcionarmos nossas lentes para as representações sobre o professorcolaborador, constatamos que, de forma recorrente, o aluno-mestre expressa veementemente sua atitude sobre esse profissional durante as atividades desenvolvidas de estágio. Nessa perspectiva, destacamos que "usamos a língua para aprovar e desaprovar; para expressar crença, opinião, dúvida; para incluir no grupo social ou excluir dele; para cumprimentar, conversar, despedir-se; em todas essas e muitas outras formas" (Halliday 2003 [1973]: 361).

Realizado na metafunção interpessoal da linguagem, o sistema de avaliatividade foi considerado na análise dos dados, em especial o sistema de atitude, o qual envolve três regiões semânticas, conforme Martin e White (2005: 42): emoção (afeto); ética (julgamento) e estética (apreciação). Nesse sentido, nas palavras de Vian Jr. (2009: 111),

Ao considerarmos as formas como ocorrem os mecanismos de avaliação do ponto de vista de sua realização léxico-gramatical, temos uma vasta gama de escolhas disponíveis no sistema linguístico. Podemos, por exemplo, ser mais ou menos intensos, pouco ou muito enfáticos, mais ou menos distantes de nossos interlocutores, muito ou pouco formais. Isso equivale a dizer que a linguagem oferece mecanismos diversos para que atribuamos diferentes avaliações aos mais diferentes aspectos de nossas atitudes em nosso cotidiano.

Nos exemplos analisados nas subseções seguintes, utilizamos o parágrafo do relatório de estágio como extensão dos excertos exemplificados. Os excertos foram precedidos por uma breve descrição da organização textual do relatório. Para auxiliar a análise, marcamos os 
limites dos complexos oracionais com três barras justapostas (///), das orações simples com duas barras (//) e de outros constituintes sobressalentes com uma barra (/). Todas as referências realizadas ao professorcolaborador foram enumeradas de forma sobrescrita e destacadas com itálico. As ocorrências dessas referências, suas realizações gramaticais e representações expressas foram listadas abaixo de cada excerto reproduzido nos exemplos. Os processos utilizados junto ao professorcolaborador como participante foram sublinhados com linha reta, ao passo que as formas gramaticais que expressam avaliatividade foram sublinhadas com linha ondulada. Alguns processos mais relevantes do nosso ponto de vista, utilizados junto ao aluno-mestre como participante, normalmente utilizados em orações projetoras, foram sụḅlị̣hạḍ̣s. com linha pontilhada. Quando utilizarmos terminologias da LSF, cujos conceitos não são pouco frequentes em estudos científicos, utilizamos notas de final de página para apresentar os referidos conceitos.

\subsection{Atitude positiva sobre o professor-colaborador}

O Exemplo 1 foi reproduzido a partir de um relato reflexivo redigido numa única lauda, inserida num relatório de estágio, o qual nos remete aos portfólios tradicionalmente utilizados no domínio escolar (Silva: 2012a). A extensão do relato corresponde ao espaço da escrita reflexiva profissional, utilizado pelo aluno-mestre na última disciplina de estágio da licenciatura. Essa escrita se caracteriza essencialmente pela "reflexão retrospectiva", no termo proposta por Perrenoud (2002). Ao relatar superficialmente algumas experiências vivenciadas na escola básica, o aluno-mestre tece brevemente comentários sobre a ação do professor-colaborador e dele próprio nesse contexto de ensinoaprendizagem, sem realizar antecipações de planejamento de atividades futuras a partir das práticas comentadas.

O aluno-mestre destaca três aspectos considerados nas aulas ministradas por ele no estágio: ensino da língua falada e escrita a ser utilizada pelos alunos, independente das exigências das normas cultas; desenvolvimento de aulas bem mais atrativas; e variação de material didático para alcançar os objetivos didáticos delineados. Os dois últimos aspectos parecem apresentados em contraposição à prática de ensino observada na instituição colaboradora. 


\begin{tabular}{|c|c|c|}
\hline \multicolumn{3}{|l|}{ EXEMPLO 1} \\
\hline \multicolumn{3}{|c|}{$\begin{array}{l}\text { Ao chegarmos ao Colégio estadual Jorge Amado, / fomos bem recebidas }{ }^{1} \text { pelo professor } / / \\
{ }^{2} \text { que nos orientou quanto ao conteúdo // que já estava sendo desenvolvido }{ }^{3} \varnothing \text { e referente à } \\
\text { participação dos alunos, e nas atividades a serem trabalhadas }{ }^{4} \varnothing \text { pedindo } / / \text { que levássemos } \\
\text { novidades para a sala de aula. } / / / \mathrm{E}^{5} \varnothing \text { ficou satisfeito com a nossa seriedade nos trabalhos } \\
\text { desenvolvidos durante o estágio. ( } 8^{\mathrm{o}} \text { período, } 2006.1,1^{\circ} \text { Ano - Ensino Médio) }\end{array}$} \\
\hline OCORRÊNCIA & FORMA GRAMATICAL & REPRESENTAÇÃO \\
\hline 1 pelo professor & $\begin{array}{l}\text { sintagma preposicional } \\
\text { (adjunto) }\end{array}$ & $\begin{array}{l}\text { Ator - Processo Material Transformati- } \\
\text { vo: agente autônomo. }\end{array}$ \\
\hline 2 que & grupo nominal (sujeito) & $\begin{array}{l}\text { Ator - Processo Material Transformati- } \\
\text { vo: agente autônomo. }\end{array}$ \\
\hline $3 \varnothing$ & $\begin{array}{l}\text { elipse - sintagma preposi- } \\
\text { cional (adjunto) }\end{array}$ & $\begin{array}{l}\text { Ator - processo material criativo: agen- } \\
\text { te autônomo. }\end{array}$ \\
\hline $4 \varnothing$ & $\begin{array}{l}\text { elipse - grupo nominal } \\
\text { (sujeito) }\end{array}$ & $\begin{array}{l}\text { Dizente - Processo Verbal: agente } \\
\text { autônomo. }\end{array}$ \\
\hline $5 \varnothing$ & $\begin{array}{l}\text { elipse - grupo nominal } \\
\text { (sujeito) }\end{array}$ & $\begin{array}{l}\text { Portador - Processo Relacional Atribu- } \\
\text { tivo: caracterizado indiretamente por. }\end{array}$ \\
\hline
\end{tabular}

O parágrafo reproduzido no Exemplo 1 é a única passagem do relato reflexivo em que o professor-colaborador é mencionado diretamente. Nos relatórios investigados, a recepção do aluno-mestre pelo professor, para realização do estágio, especialmente das atividades de regência de aulas, é frequentemente descrita de forma positiva nos relatórios. A título de ilustração, essa apreciação favorável à representação do professor é marcada diretamente pelo Modalizador bem. A apreciação é corroborada pela escolha lexical do Processo Verbal realizada pela forma nominal no gerúndio pedindo, seguida por uma oração projetada no modo subjuntivo (que levássemos novidades para a sala de aula). A oração verbal evidencia o diálogo do aluno-mestre com o professorcolaborador, o qual demanda a colaboração da universidade para as aulas na educação básica.

No primeiro complexo oracional do Exemplo 1, identificamos a representação do professor-colaborador como agente autônomo de quatro processos, sendo o último já focalizado no parágrafo anterior. Esse professor atua em função do desencadeamento de algumas atividades a serem exercidas pelo aluno-mestre no estágio supervisionado. Nas três primeiras ocorrências, o professor colaborador é representado como Ator de Processos Materiais (fomos recebidas; orientou; estava sendo desenvolvido). O excerto é representativo do tipo de apagamento 
que o professor sofre nos relatórios, o que pode ser observado pelas construções na "forma receptiva" (fomos recebidas; estava sendo desenvolvido $)^{17}$, quando o Ator dos Processos Materiais é realizado no sintagma preposicionado pelo professor e sua elipse $(\varnothing)$ no final das orações, respectivamente. No quarto Processo (pedindo), também há uma elipse do Dizente-professor (Ø). Junto ao Processo Material orientou, encontramos o pronome relativo que na posição temática retomando o sintagma preposicionado mencionado e exercendo a função de Ator-professor do Processo Material.

Ainda no Exemplo 1, o professor-colaborador é caracterizado pelo aluno-mestre por meio de uma oração relacional atributiva ( $E$ Ø ficou satisfeito com a nossa seriedade nos trabalhos desenvolvidos durante o estágio). Mais uma vez, a elipse de um grupo nominal referente ao professor é registrada, favorecendo nossa hipótese de invisibilização do professor colaborador, mesmo considerado a produtividade do fenômeno linguístico na escrita do português. O Processo Relacional se configura como uma forma gramatical marcada da escrita reflexiva profissional, pois a apreciação por meio do Atributo é inevitável, quando o professor-colaborador é representado na função de Portador. O Atributo selecionado (satisfeito) caracteriza o estado do professorportador após as atividades realizadas pelo aluno-mestre, desdobrandose na autorrepresentação positiva do próprio escritor, autocaracterizado pela seriedade. Desempacotando o Circunstante Causal (com a nossa seriedade nos trabalhos desenvolvidos durante o estágio), podemos encontrar orações como: fomos sérios nos trabalhos que realizamos no estágio; ou desenvolvemos trabalhos sérios no estágio. Considerando que a escrita focalizada é utilizada como instrumento de avaliação do aluno-mestre na disciplina, tal oração relacional parece acionada, ao final do parágrafo, após o relato de ações assumidas pelo professorcolaborador, como estratégia argumentativa de convencimento do professor-supervisor a respeito do desempenho do aluno-mestre no estágio.

O Exemplo 2 corresponde a um parágrafo reproduzido da seção intitulada "A EXPERIÊNCIA", integrante de um relatório de estágio 
mais extenso e detalhado que o texto focalizado no exemplo anterior. $\mathrm{O}$ aluno-mestre demonstra esforço para compreender, por diferentes perspectivas, a complexidade da situação por ele experienciada na escola básica, sem responsabilizar o professor-colaborador por situações adversas, o que justifica a reprodução do excerto nesta subseção - Atitudes Positivas. São mencionados como desafios para a prática do magistério aspectos politicos, históricos e sociais, envolvendo as seguintes demandas percebidas pelo aluno-mestre: participação dos pais, materiais e recursos didáticos, infraestrutura da escola e formação do professor em serviço.

A escrita do relatório é marcada pelas reflexões "retrospectiva" e "prospectiva", nos termos definidos por Perrenoud (2002), pois, após analisar algumas situações mais relevantes e mais marcantes, vivenciadas na escola básica, o aluno-mestre reflete sobre futuras ações a serem assumidas para o contexto experienciado. Os sentidos dessas categorias propostas por Edge (2011) também são relevantes aqui, pois tanto o "efeito do trabalho sobre a pessoa" - retrospectiva-, quanto "o efeito da pessoa sobre o trabalho" - prospectiva -, são discutidos no relatório.

\begin{tabular}{|c|c|c|}
\hline \multicolumn{3}{|l|}{ EXEMPLO 2} \\
\hline \multicolumn{3}{|c|}{ 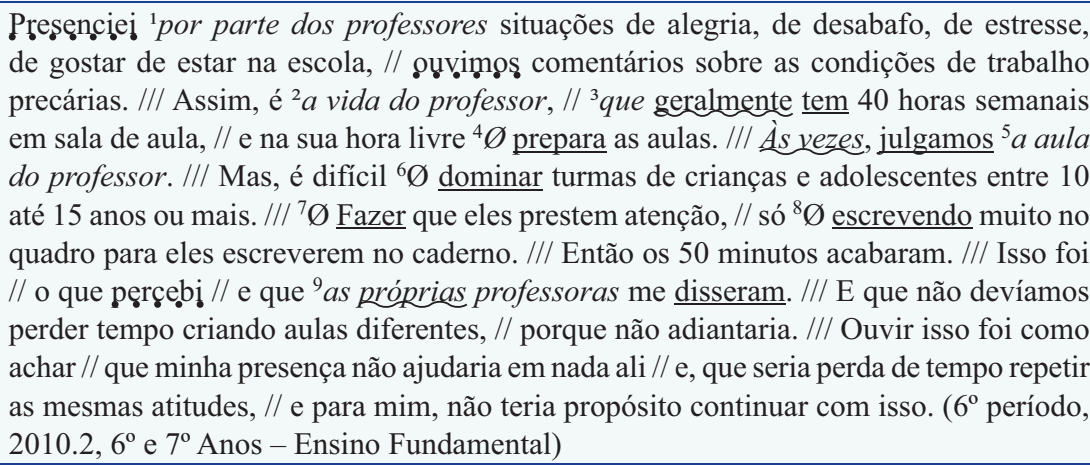 } \\
\hline OCORRÊNCIA & FORMA GRAMATICAL & REPRESENTAÇÃO \\
\hline & & $\begin{array}{l}\text { Portador, Dizente, Experiencia- } \\
\text { dor - Processos Relacional, Verbal, } \\
\text { Mental: caracterizado por/agente } \\
\text { autônomo. }\end{array}$ \\
\hline & grupo nominal (sujeito) & $\begin{array}{l}\text { Portador - Processo Relacional: } \\
\text { caracterizado indiretamente por. }\end{array}$ \\
\hline
\end{tabular}




\begin{tabular}{|l|l|l|}
\hline 3 que & $\begin{array}{l}\text { elipse (grupo nominal - } \\
\text { sujeito) }\end{array}$ & $\begin{array}{l}\text { Possuidor - Processo Possessivo: } \\
\text { caracterizado diretamente por. }\end{array}$ \\
\hline $4 \varnothing$ & $\begin{array}{l}\text { elipse (grupo nominal - } \\
\text { sujeito) }\end{array}$ & $\begin{array}{l}\text { Ator - Processo Material Criativo: } \\
\text { agente autônomo. }\end{array}$ \\
\hline $\begin{array}{l}5 \text { a aula do pro- } \\
\text { fessor }\end{array}$ & $\begin{array}{l}\text { grupo nominal (comple- } \\
\text { mento) }\end{array}$ & $\begin{array}{l}\text { Meta - Processo Material Transfor- } \\
\text { mativo: alvo indireto. }\end{array}$ \\
\hline $6 \varnothing, 7 \varnothing, 8 \varnothing$ & $\begin{array}{l}\text { elipse (grupo nominal - } \\
\text { sujeito) }\end{array}$ & $\begin{array}{l}\text { Atores - Processos Materiais } \\
\text { Transfor-mativos e criativo: agente } \\
\text { autônomo. }\end{array}$ \\
\hline $\begin{array}{l}9 \text { as próprias pro- } \\
\text { fessoras }\end{array}$ & grupo nominal (sujeito) & $\begin{array}{l}\text { Dizente - Processo Verbal: agente } \\
\text { autônomo. }\end{array}$ \\
\hline
\end{tabular}

No primeiro complexo oracional do Exemplo 2, o parágrafo é iniciado com o Processo Comportamental (presenciei) na posição de Tema Marcado da primeira oração. Na segunda, também identificamos um Processo Comportamental (ouvimos). Nessas orações, o aluno-mestre se autorrepresenta como Comportante, elas são indícios da reflexão retrospectiva pela escrita. Nas palavras de Halliday e Matthiessen (2014: 109), esse tipo de processo "expressa ato de consciência física envolvendo percepção", ou seja, o aluno-mestre experienciou pelos sentidos fisiológicos diferentes situações rotineiramente vivenciadas por professores.

Na primeira ocorrência, o núcleo do grupo nominal (situações), complemento do Processo Comportamental (presenciei), é caracterizado pela parataxe de sintagmas preposicionais na função de qualificador (de alegria, de desabafo, de estresse, de gostar de estar na escola). Tais qualificadores evidenciam uma mistura de momentos agradáveis e adversos no trabalho docente, caracterizam o estado desses profissionais (alegria; estresse), e representam-nos como agentes de experiência (gostar) e de enunciados (desabafo; comentários). Na segunda ocorrência, o complemento do Processo Comportamental (comentários) é caracterizado por uma "circunstância de projeção de assunto" (sobre as condições de trabalho precárias). Os professores da escola básica estão no centro do contexto descrito, representados gramaticalmente no sintagma preposicional por parte dos professores.

No segundo complexo oracional, o advérbio assim é utilizado como Atributo da oração relacional, que tem a vida do professor como Portador. Tal forma adverbial encapsula a caracterização prévia da situação 
do trabalho docente e, também, exerce a função catafórica, anunciando as duas orações subsequentes do complexo oracional, as quais trazem informações adicionais sobre o referido Portador. Essa construção do grupo nominal com a professora colaboradora integrando o sintagma preposicional modificador é bastante recorrente nos dados investigados e requer maiores estudos. No Exemplo 2, há outra ocorrência de grupo nominal desse tipo (a aula do professor), o qual se configura como uma escolha gramatical que focaliza diretamente o núcleo semântico do grupo nominal. Concebemo-lo como uma estratégia para a invisibilização do professor-colaborador.

Ainda focalizando o segundo complexo oracional, identificamos uma oração relacional possessiva (que geralmente tem 40 horas semanais em sala de aula), que contribui para a caracterização de a vida do professor. O pronome relativo que exerce a função de Possuidor. Ele retoma diretamente o núcleo semântico do sintagma preposicional (professor). $\mathrm{O}$ volume de carga horária apresentado no complemento do Processo Relacional contribui para caracterizar uma das adversidades no exercício da docência, mesmo sendo utilizado um Modalizador (geralmente). Pelo mecanismo de parataxe, a oração material e na sua hora livre prepara as aulas, com o Ator-professor elíptico (Ø), contribui para a construção da representação do colaborador como agente autônoma, mesmo que o Processo Material (prepara) seja apresentado como uma atribuição adversa na docência, pois é realizada no tempo livre que deveria ser desfrutado pelo professor. O Circunstante de Tempo é bastante relevante para o discurso construído (sua hora livre).

O grupo nominal a aula do professor, a que fizemos referência previamente, funciona como Meta do Processo Material (julgamos) realizado pelo aluno-mestre. Ao assumir a primeira pessoa do plural, o escritor parece se autorrepresentar, juntamente com outros alunosmestre, como responsável pelo Processo, o qual, por sua vez, é modalizado a partir do Circunstante de Gradação na posição temática da oração (Às vezes). Interpretamos esse julgamento precipitado da prática do professor como um indício das representações negativas sobre o professor a que faz referência Kleiman (2009, 2006), conforme discutimos na seção Prática reflexiva do professor. 
Essas representações são reproduzidas, inclusive, na própria universidade, onde situações instauradas podem ser aproveitadas para a criação de atitudes positivas sobre o professor. No excerto analisado, podemos considerar o relato de alguns desafios enfrentados pelos professores como uma situação a ser aproveitada para desconstrução de representações negativas sobre esse profissional. Os Processos Materiais dominar, fazer e escrevendo, realizados nas formas nominais do infinitivo e gerúndio, semiotizam difíceis atribuições do magistério. São utilizados em orações contrapostas ao suposto julgamento do professor, a partir da conjunção Mas na posição temática.

Essas orações contrapostas trazem a voz dos professores para a escrita reflexiva, a qual é, explicitamente, marcada pelo Processo Verbal (disseram) utilizado no complexo oracional subsequente. O Dizente (as próprias professoras) é composto pelo Qualificador próprias, marcando explicitamente uma Gradação de Foco ${ }^{18}$. Pela atitude expressa, o alunomestre provavelmente fora surpreendido pelas revelações realizadas pelos professores durante o estágio obrigatório. Talvez, tais revelações pudessem ser esperadas de outros atores sociais na escola, mas não de professores supostamente tão motivados quanto o aluno-mestre ao final da licenciatura.

O discurso sobre adversidades não foi apenas propagado pelo professor- colaborador. As adversidades também foram observadas pelo aluno-mestre representado na função de Experienciador elíptico, conforme semiotizado no Processo Metal Perceptivo percebi. Utilizado na posição temática e com função anafórica, o pronome isso encapsula parte do enunciado projetado pelos Processos disseram e percebi. $\mathrm{O}$ complexo oracional subsequente também corresponde ao enunciado reportado pelos Processos mencionados, na forma de um conselho oferecido pelos professores ( $E$ que não devíamos perder tempo criando aulas diferentes, porque não adiantaria.). Tal enunciado desmotivou o aluno-mestre diante das atividades de ensino a serem desenvolvidas no estágio, o que é bastante é evidente no último complexo oracional

18. De acordo com Martin e White (2005: 137), a gradação de foco "opera em taxinomias experienciais onde as categorias são mais ou menos precisamente determinadas por algumas combinações de condições necessárias e suficientes. Nesse caso, gradação opera para reconstruir essas categorias de tal maneira que elas participem de uma escala prototípica". 
do excerto, onde encontramos uma relacional como oração principal, sendo o Processo Mental Perceptivo ouvir utilizado como parte do Portador (Ouvir isso foi como achar que minha presença não ajudaria em nada ali e, que seria perda de tempo repetir as mesmas atitudes, $e$ para mim, não teria propósito continuar com isso). Em outras palavras, tal complexo oracional caracteriza a sensação de desapontamento do aluno-mestre ao ouvir os conselhos dos professores.

Dado o último excerto analisado, questionamos a respeito do papel do professor-colaborador nos estágios das licenciaturas. Desmotivar o aluno-mestre não deveria ser o papel exercido por ele, porém não é possível nem desejável omitir as adversidades do real contexto de atuação profissional do professor. Na universidade focalizada, o estágio permite a inserção do aluno-mestre na realidade das escolas públicas locais. Apesar das adversidades experienciadas, o aluno-mestre optou pelo risco da inovação da prática pedagógica, conforme constatável na leitura completa do relatório. A avaliação da própria prática foi positiva diante dos resultados imediatos.

O que teria a dizer o professor-colaborador a respeito do trabalho desenvolvido pelo aluno-mestre? Uma resposta para perguntas desse tipo não aparece nos relatórios investigados. O papel do professorcolaborador não pode se restringir ao relato de adversidades em sua prática pedagógica. É desejável uma maior interação entre o professorcolaborador e o aluno-mestre. Dessa interação, pode surgir uma motivação mútua entre tais atores sociais, contribuindo inclusive para evitar atitudes negativas sobre a atuação docente na escola básica, conforme as analisadas na próxima subseção.

\subsection{Atitude negativa sobre o professor-colaborador}

O Exemplo 3 foi reproduzido a partir de um relatório ainda mais extenso que o do excerto analisado previamente. Outra distinção relevante no relatório são reproduções de algumas atividades didáticas, tanto das aulas observadas do professor-colaborador quanto das ministradas pelo aluno-mestre. Tais exemplos ocupam uma extensão significativa do relatório, quando são contextualizados e analisados, inclusive, a partir de literaturas científicas assumidas como referências. 
As análises se desdobram em reflexões "retrospectiva" e "prospectiva", nos dois sentidos discutidos previamente.

O excerto está inserido na seção "PRÁTICAS DE ENSINO DE LÍNGUA PORTUGUESA", situada logo após a introdução do relatório. A seção foi destinada ao enfoque das aulas observadas pelo alunomestre, as quais foram caracterizadas pela prática de ensino da tradição do ensino de Língua Portuguesa. Diferentemente do que, frequentemente, observamos nos relatórios de estágio, o aluno-mestre não apenas apresenta uma análise crítica da prática observada, mas ministra aulas apresentadas como uma alternativa inovadora às atividades criticadas. O excerto funciona como um parágrafo conclusivo das análises das atividades didáticas propostas pelo professor-colaborador.

\begin{tabular}{|c|c|c|}
\hline \multicolumn{3}{|l|}{ Exemplo 3} \\
\hline \multicolumn{3}{|c|}{ 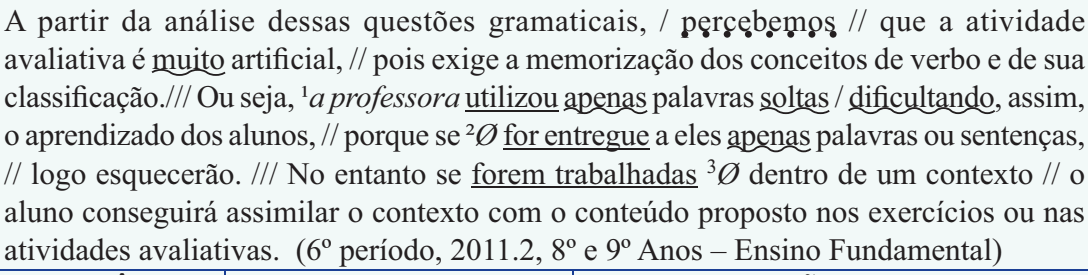 } \\
\hline OCORRÊNCIA & FORMA GRAMATICAL & REPRESENTAÇÃO \\
\hline 1 a professora & grupo nominal (sujeito) & $\begin{array}{l}\text { Ator - Processo Material Transfor- } \\
\text { mativo: agente autônomo de processo } \\
\text { avaliado negativamente. }\end{array}$ \\
\hline $2 \varnothing$ & $\begin{array}{l}\text { elipse (grupo nominal } \\
\text {-sujeito) }\end{array}$ & $\begin{array}{l}\text { Ator - Processo Material Transforma- } \\
\text { tivo: agente autônomo hipotético de } \\
\text { processo avaliado negativamente. }\end{array}$ \\
\hline $3 \varnothing$ & $\begin{array}{l}\text { elipse (sintagma preposi- } \\
\text { cional - adjunto) }\end{array}$ & $\begin{array}{l}\text { Ator - Processo Material Transforma- } \\
\text { tivo: agente autônomo hipotético de } \\
\text { processo avaliado positivamente. }\end{array}$ \\
\hline
\end{tabular}

No primeiro complexo oracional, a análise das atividades didáticas é representada na posição de Tema Marcado (A partir da análise dessas questões gramaticais), o qual serve de ancoragem para o aluno-mestre, na função de Experienciador, expressar sua atitude diante das atividades analisadas. Tal atitude é expressa pelo Processo Mental Perceptivo percebemos, projetando uma oração relacional que expressa apreciação da prática do professor-colaborador (que a atividade avaliativa é muito artificial). Nessa oração, o Portador (a atividade avaliativa) é 
caracterizado por um atributo marcado por uma gradação (muito) que intensifica a atitude negativa também sinalizada pela escolha lexical do núcleo do grupo nominal (artificial). A justificativa para tal apreciação é apresentada a partir do recurso de expansão por intensificação, a partir do uso de uma oração mental (pois exige a memorização dos conceitos de verbo e de sua classificação), que representa o estudo da gramatica em desacordo com as atuais propostas para as aulas de língua materna, no quarto ciclo do ensino fundamental.

No segundo complexo oracional, o professor-colaborador (a professora) é representado como agente autônomo responsável por um Processo Material (utilizou) que sofre uma gradação negativa de força pelo uso da forma adverbial (apenas). A atitude negativa é corroborada: pelo grupo nominal (palavras soltas) na função de Escopo, o qual é formado por um Qualificador (soltas) que contribui para caracterizar o tipo de estudo da gramática proposto na escola ${ }^{19}$; pela forma verbal no gerúndio (dificultando) introduzindo uma expansão que realça as consequências da prática pedagógica utilizada; e pelas duas últimas orações articuladas pela hipotaxe, representando a provável causa do trabalho improdutivo com a gramática em sala de aula. Esse complexo oracional está articulado ao anterior pelo recurso de elaboração por clarificação, sinalizada pela expressão conjuntiva $O u$ seja, na posição temática ${ }^{20}$.

O Processo Material for entregue, utilizado no futuro do subjuntivo, articulado ao Processo Mental Cognitivo (esquecerão), no futuro do indicativo, representa uma relação condicional entre orações assumida como certa pelo aluno-mestre. Essa certeza advém do conhecimento teórico adquirido pelo aluno-mestre na universidade. $\mathrm{O}$ professor-colaborador é representado como Ator $(\varnothing)$ responsável pelo desdobramento de um processo futuro, indesejado do ponto de vista pedagógico, em que o aluno da escola básica é representado como Experienciador. Mais uma vez, temos uma gradação negativa de força pelo uso da forma adverbial (apenas).

19. De acordo com Halliday e Matthiessen (2014: 239) e Thompson (2014: 112), o Escopo (Scope) não é afetado pela performance desencadeada no Processo.

20. De acordo com Halliday e Matthiessen (2014: 463), na clarificação (clarification), "a oração secundária clarifica a tese da primeira oração, apoiando essa última com alguma forma de explanação ou comentário explanatório”. 
O terceiro complexo oracional está articulado ao anterior pelo recurso da expansão por intensificação, sinalizado pela expressão conjuntiva na posição de tema marcado (No entanto). Entre as orações articuladas pela hipotaxe, mais uma vez, encontramos uma relação condicional entre orações representando um saber acadêmico possuído pelo aluno-mestre. O professor-colaborador é representado como Ator (Ø forem trabalhados) responsável pelo desdobramento de um processo futuro (conseguirá assumir), em que o aluno é representado como Experienciador. Desta vez, o desdobramento está coerente com as atuais propostas para o ensino de Língua Portuguesa.

A relação semântica condicional representada no exemplo focalizado ilustra o movimento discursivo de reflexão prospectiva, no termo de Perrenoud (2002), realizado pelo aluno-mestre, o que parece ser bastante produtivo para o desenvolvimento do letramento do professor em formação inicial. A experiência vivenciada desencadeia a reflexão ou criação de alguma situação futura de ensino, a qual se espera mais produtiva para a educação básica. Tal situação também é pensada a partir de saberes teóricos de referência.

O Exemplo 4 foi redigido numa lauda e meia, sendo a estrutura esquemática bastante próxima ao relato focalizado a partir do primeiro exemplo reproduzido neste artigo. Ambos foram produzidos em turmas diferentes do último período da Licenciatura em Letras, porém, no mesmo semestre letivo e sob a regência do mesmo professor formador. Esse fato evidencia a interferência do contexto de situação na produção textual, ademais, conforme constatamos em pesquisa anterior (Silva 2012a: 293), o professor formador e a licenciatura são as variáveis determinantes da estrutura esquemática do gênero ou estrutura potencial do gênero - EPG.

O exemplo reproduzido ilustra as reflexões sutis semiotizadas ao longo do texto intitulado "RELATÓRIO DO ESTÁGIO DE OBSERVAÇÃO". Muitas vezes, a atitude do aluno-mestre diante de tais atividades se torna mais evidente pelo encadeamento das experiências compartilhadas. Nesse relato, são apresentadas apenas as experiências vivenciadas nas aulas observadas na educação básica, as das aulas ministradas pelo aluno-mestre foram relatadas em outro texto intitulado "RELATÓRIO DE ESTÁGIO". 
O Exemplo 4 é representativo dos outros dois parágrafos componentes da parte central do texto, tanto no tocante ao encadeamento das ações relatadas, quanto ao conteúdo tematizado pelo aluno-mestre. Em outras palavras, a prática pedagógica experienciada pelo aluno-mestre se repete nas diferentes turmas onde as aulas foram observadas.

\begin{tabular}{|c|c|c|}
\hline \multicolumn{3}{|l|}{ Exemplo 4} \\
\hline \multicolumn{3}{|c|}{ 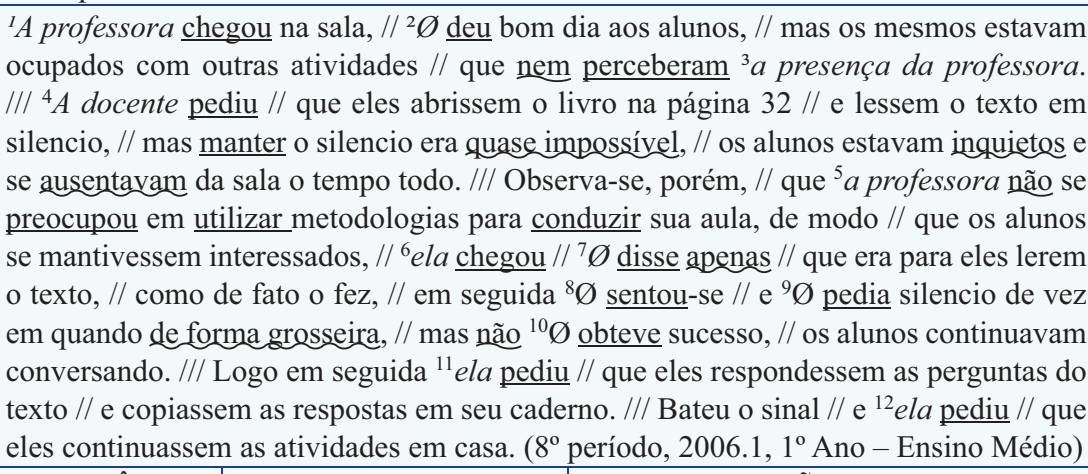 } \\
\hline OCORRÊNCIA & FORMA GRAMATICAL & REPRESENTAÇÃO \\
\hline 1 a professora & grupo nominal (sujeito) & $\begin{array}{l}\text { Ator - Processo Materi } \\
\text { vo: agente autônomo }\end{array}$ \\
\hline $2 \varnothing$ & grupo nominal - & $\begin{array}{l}\text { Dizente - Processo Verbal: responsável } \\
\text { por enunciado proferido. }\end{array}$ \\
\hline $\begin{array}{l}3 \text { a pres } \\
\text { profess }\end{array}$ & & \\
\hline 4 a docente & grupo nominal (sujeito) & $\begin{array}{l}\text { Dizente - Processo Verbal: responsável } \\
\text { por enunciado proferido. }\end{array}$ \\
\hline 5 a professora & grupo nominal (sujeito) & $\begin{array}{l}\text { Experienciador - Processo Mental: } \\
\text { agente autônomo de processo avaliado } \\
\text { negativamente. }\end{array}$ \\
\hline 6 ela & grupo nominal (sujeito) & $\begin{array}{l}\text { Ator - Processo Material Transformati- } \\
\text { vo: agente autônomo. }\end{array}$ \\
\hline $7 \varnothing$ & $\begin{array}{l}\text { elipse (grupo nominal - } \\
\text { sujeito) }\end{array}$ & $\begin{array}{l}\text { Dizente - Processo Verbal: responsável } \\
\text { por um enunciado proferido avaliado } \\
\text { negativamente. }\end{array}$ \\
\hline $8 \varnothing$ & $\begin{array}{l}\text { elipse (grupo nominal - } \\
\text { sujeito) }\end{array}$ & $\begin{array}{l}\text { Ator - Processo Material Transformati- } \\
\text { vo: agente autônomo. }\end{array}$ \\
\hline $9 \varnothing$ & $\begin{array}{l}\text { elipse (grupo nominal - } \\
\text { sujeito) }\end{array}$ & $\begin{array}{l}\text { Dizente - Processo Verbal: responsável } \\
\text { por um enunciado proferido avaliado } \\
\text { negativamente. }\end{array}$ \\
\hline $10 \varnothing$ & $\begin{array}{l}\text { elipse (grupo nominal } \\
\text {-sujeito) }\end{array}$ & $\begin{array}{l}\text { Ator - Processo Material Transformati- } \\
\text { vo: agente autônomo avaliado negativa- } \\
\text { mente. }\end{array}$ \\
\hline
\end{tabular}




\begin{tabular}{|l|l|l|}
\hline 11 ela & grupo nominal (sujeito) & $\begin{array}{l}\text { Dizente - Processo Verbal: responsável } \\
\text { por um enunciado proferido. }\end{array}$ \\
\hline 12 ela & grupo nominal (sujeito) & $\begin{array}{l}\text { Dizente - Processo Verbal: responsável } \\
\text { por um enunciado proferido. }\end{array}$ \\
\hline
\end{tabular}

No primeiro complexo oracional, identificamos uma atitude negativa do aluno-mestre diante dos fatos relatados. Essa atitude é marcada pelo encadeamento de Processos atribuídos ao professor-colaborador. Nas duas primeiras orações, esse profissional (o professor) é, respectivamente, o Ator e o Dizente dos Processos Material (chegou) e Verbal (deu) instanciados. A conjunção adversativa mas introduz uma oração relacional (os mesmos estavam ocupados com outras atividades) que caracteriza ausência de resposta adequada dos alunos diante do cumprimento da professora. Tal reação é enfatizada pelo encadeamento final da oração mental (que nem perceberam a presença da professora), quando o professor-colaborador é representado como Fenômeno ignorado (a presença da professora). A atitude negativa é explicitamente marcada pelo adjunto de modo nem. As cinco orações são articuladas a partir da extensão por expansão, realçando o processo sociossemiótico de relatar.

No segundo complexo oracional, mais uma vez, ações da professora-colaboradora e reações dos alunos são contrapostas pela conjunção adversativa mas. Uma investigação mais extensa pode confirmar tal contraposição como estratégia de elaboração da escrita reflexiva profissional. A primeira oração projeta o comando para atividade de leitura dado pela professora ( $A$ docente pediu). A reação dos alunos é caracterizada pelas duas orações relacionais (manter o silencio era quase impossivel; os alunos estavam inquietos) e uma oração material (e se ausentavam da sala o tempo todo), justapostas após a conjunção adversativa.

Na primeira oração relacional, encontramos um Portador composto por uma oração material reduzida (manter o silêncio). É caracterizado por um Atributo negativo composto pelo Modalizador adjunto de gradação (quase) e pelo adjetivo (impossível) formado pelo prefixo de negação im-. Ao professor-colaborador, parece ser atribuída a função do Ator mal sucedido responsável pela manutenção do silêncio na sala de aula. Na segunda oração, os alunos são representados como Portador, os quais são caracterizados pela negação, também marcada 
pelo prefixo in- componente do atributo (inquietos). Na oração material, os alunos são representados como atores do processo material (ausentavam) que configura um comportamento indesejado, um tipo de afronta ao professor em sala de aula.

O terceiro complexo oracional é iniciado por um Processo Mental Perceptivo (observa) que projeta vários processos atribuídos ao professor-colaborador, evidenciando que as atividades relatadas passam inicialmente pela percepção do aluno-mestre. Novamente, orações são contrapostas por meio da conjunção adversativa mas. Desta vez, a conjunção sinaliza um resultado indesejado do encadeamento de Processos assumidos pela professora-colaboradora, que exerce a função de Ator (chegou; sentou) e Dizente (disse; pediu). O resultado indesejado é representado por meio de uma oração relacional possessiva, na qual o professor-colaborador é representado pela elipse do Portador (Ø), ao passo que o processo relacional (obteve) é negado pelo Modalizador de negação (não). Assim como na oração relacional, o Processo Mental Cognitivo (preocupou) é negado na segunda oração, quando o professor-colaborador é representado como Experienciador (a professora). Ambos os processos negados correspondem a participações desejadas para os professores na escola básica, porém, não foram observadas pelo aluno-mestre no estágio realizado.

Os Modalizadores apenas e de forma grosseira realçam o envolvimento do aluno-mestre na escrita reflexiva profissional. O primeiro traz uma gradação de foco para o Processo Verbal, evidenciado a insuficiência de instruções dadas pelo professor-colaborador. O segundo caracteriza a maneira indesejável como o professor-colaborador interagiu com o aluno-mestre.

Os dois últimos complexos oracionais também são representativos do encadeamento de orações em função da representação da prática docente experienciada nos estágios supervisionados. Ambos os complexos são iniciados por formas gramaticais na posição de tema marcado (Logo em seguida; Bateu o sinal), indicando a sequência temporal das atividades propostas pelo professor-colaborador. Ele é representado como Dizente (ela) de orações verbais projetoras idênticas. As orações projetadas representam os comandos das atividades propostas pelo professor-colaborador. Esses comandos são realizados pelo discurso indireto. 
Finalmente, o professor colaborador é representado no Exemplo 4 como agente autônomo de comandos para atividades, desprovidos de maiores explicações que pudessem despertar o envolvimento dos alunos. $\mathrm{O}$ encadeamento de orações contribui para a construção de um contexto de ensino monótono. As marcas de reflexão são bastante sutis nesse registro, o que não significa ausência de ganhos para o letramento do professor em formação inicial. Em outro relato escrito, quando focaliza as próprias aulas ministradas, o aluno-mestre revela o esforço para realizar aulas mais produtivas, em resposta às atividades de ensino experienciadas durante o estágio de observação. Esse fato mostra que a reflexão retrospectiva, no sentido proposta por Perrenoud (2002), foi realizada em algum momento.

\section{Considerações finais}

A caracterização do contexto acadêmico de uso da escrita reflexiva profissional, a partir da literatura científica produzida em diferentes áreas do conhecimento, mostrou a relevância da reflexão do alunomestre sobre a prática pedagógica na educação básica proporcionada pelo estágio supervisionado obrigatório da licenciatura. Essa escrita pode contribuir para a formação crítica do professor, ainda que diversos relatórios revelem uma reflexão bastante tímida sobre as experiências vivenciadas pelo aluno-mestre na escola básica, o que acreditamos ser justificado pela ausência de apropriação pedagógica produtiva desse registro no estágio supervisionado, o qual, por sua vez, ainda parece ser reduzido ao simples cumprimento de carga horário com atividades didáticas em contextos de instrução formal.

As realizações gramaticais identificadas, responsáveis por caracterização da escrita reflexiva profissional e por representações do professor-colaborador do estágio supervisionado, foram: (1) orações projetoras com os alunos-mestre representados como experienciador do fato relatado; (2) contrajunção de fatos experienciados representados por meio da expansão de orações, a partir de formas linguísticas conjuntivas; (3) justaposição de orações materiais, verbais ou mentais, nas quais o professor-colaborador é representado como Ator, Dizente ou Experienciador; (4) orações relacionais nas quais o professorcolaborador é representado como portador; e (5) formas linguísticas 
diversas, como adjunto de modo e qualificador em grupo nominal, expressando avaliatividade.

Na realização gramatical (1), são comuns ocorrências de orações relacionais projetadas, responsáveis pela caracterização do professor a partir da avaliação realizada pelo aluno-mestre. Usos de orações comportamentais com o aluno-mestre representado como Comportante parecem desempenhar uma função avaliativa bastante próxima da realizada (1). Na realização gramatical (2), o professor-colaborador é representado como Ator, Experienciador ou Dizente autônomo, ou seja, o Processo realizado pelo professor é reportado pelo aluno-mestre na escrita reflexiva. Porém, tais orações são contrapostas a orações que representam comportamento indesejado do aluno da escola básica ou a orações em que o professor-colaborador é representado como agente de processos idealizados pelo aluno-mestre, justificando a escolha de orações no futuro do subjuntivo. Esse último caso é responsável pela realização da reflexão prospectiva, no termo proposto por Perrenoud (2001), o que parece significativo na formação inicial do professor.

Na realização gramatical (3), o professor-colaborador também é representado como Ator, Experienciador ou Dizente autônomo das orações justapostas, resultando na construção de representações negativas. As realizações gramaticais (4) e (5) representam de forma mais explícita a avaliatividade na escrita reflexiva profissional. Essa última contribui para calibrar as representações realizadas pelas demais representações gramaticais identificadas.

A análise parece revelar ainda uma tendência de invisibilização do professor-colaborador no registro investigado, o que acontece pelo uso recorrente de formas receptivas, de retomadas do professor-colaborador por elipse e de realização do professor-colaborador como qualificador do núcleo de grupos nominais. As realizações gramaticais e representações aqui identificadas se configuram como mapeamento investigativo inicial. Ainda precisam ser aprofundadas, inclusive com ferramentas da linguística de corpus, viabilizadoras da análise quantitativa dos dados. Em nosso grupo de pesquisa, outros achados estão por ser realizados a partir do imenso banco de dados disponíveis.

O professor-colaborador não é representado como um interlocutor do aluno-mestre na escrita reflexiva profissional. O estágio precisa se 
consolidar como oportunidade de construção cooperativa de saberes entre as instituições formadoras envolvidas.

Finalmente, destacamos a contribuição proporcionada pela LSF para o percurso investigativo transdisciplinar característico da LA, realizado nesta pesquisa. Originária da referida teoria linguística, a noção de contexto de cultura proporcionou o diálogo entre disciplinas, resultando na reconstrução de algumas práticas sociais características das instituições envolvidas no estágio supervisionado da licenciatura. O reconhecimento dessas práticas nos auxiliou a contextualizar a microanálise do registro escrito investigado, considerando os estratos de realização da linguagem tomados como referência para análises na LSF. Esse percurso investigativo ainda merece maiores estudos, trata-se de um nicho investigativo alvo das nossas pesquisas na LA.

Recebido em novembro de 2013

Aprovado em junho de 2014

E-mail: wagnerodriguesilva@hotmail.com

\section{Referências bibliográficas}

EdgE, Julian. 2011. The Reflexive Teacher Educator in TESOL: Roots and Wings. New York: Routledge.

EgGINS, Suzanne. 2004. An Introduction to Systemic Functional Linguistics. London: Continuum.

Feiman-Nemser, Sharon; Beasley, Kathrene. 2007. Discovering and sharing knowledge: inventing a new role for cooperating teachers. In: D. Carroll et al. (Ed.). Transforming teacher education: reflections from the field. Cambridge, MA: Harvard Education Press. p. 139-160.

Guareschi, Pedrinho. 2008. Empoderamento. In: Danilo R. Streck; Euclides Redin; Jaime J. Zitkoski (Orgs.). Dicionário Paulo Freire. Belo Horizonte: Autêntica Editora. p. 165-166.

Grant, Carl; Zeichner, Kenneth. 1984. On becoming a reflective teacher. In: GRANT, C. (Ed.). Preparing for reflective teaching. Boston: Allyn \& Bacon. Acesso em 23 Outubro, 2013: http://www.wou. edu/ girodm/foundations/Grant and Zeichner.pdf.

FARAH, Bárbara. 2013. Representações de professores da escola básica em relatórios de estágio supervisionado da Licenciatura em Letras. Relatório Final de Iniciação Científica. Araguaína: UFT/CNPq. 
FIAD, Raquel. 2011. A escrita na universidade. Revista da ABRALIN. Paraná: UFPR, v. especial, $2^{\mathrm{a}}$ parte. p. 357-369.

; SiLVA, Lilian. 2009. Escrita na formação docente: relatos de estágio. Acta Scientiarum. Language and Culture. Maringá: EDUEM, v. 31, n. 2, p. 123-131.

Freire, Paulo. 1987. Pedagogia do oprimido. $18^{\text {a }}$ ed. Rio de Janeiro: Paz e Terra.

KLeiman, Angela. 2009. Projetos dentro de projetos: ensino-aprendizagem da escrita na formação de professores de nível universitário e de outros agentes de letramento. Scripta. Belo Horizonte: PUC/MG, v. 13, n. 24, p. 17-30.

2006. Professores e agentes de letramento: identidade e posicionamento social. Filologia e Linguística Portuguesa. São Paulo: USP, v. 8, p. 409-424.

HallidaY, Michael. 2003[1973]. The Functional Basis of Language. In: Bernstein, B. (ed.). Class, Codes and Control: Applied Studies towards a Sociology of Language. Volume II. London: Routledge. p. 343-366.

. 1989. Part A. In: Halliday, M. A. K.; Hasan, R. Language, Context and Text. $2^{\mathrm{a}}$ ed. Oxford: Oxford University Press. p. 03-50. ; Matthiessen Christian. 2014. Halliday's Introduction to Functional Grammar. $4^{\text {th }}$. Ed. London: Routledge. ; _ 1999. Construing Experience through Meaning: a Language-Based Approach to Cognition. London: Contnuum.

Hasan, Ruqaiya. 2009. The Place of Context in a Systemic Functional Model. In: Halliday, M. A. K.; Webster, J. J. (Eds.). Continuum Companion to Systemic Functional Linguistics. London: Continuum. p. 166-189.

2003[1973]. Code, register and social dialect. In: Bernstein, B. (ed.). Class, Codes and Control: Applied Studies towards a Sociology of Language. Volume II. London: Routledge. p. 253-292.

1989. Part B. In: Halliday, M. A. K.; Hasan, R. Language, Context and Text. $2^{\mathrm{a}}$ ed. Oxford: Oxford University Press. p. 52-121.

Hewings, Ann; NoRTh, Sarah. 2006. Emergent Disciplinary: a Comparative Study of Theme in Undergraduate Essays in Geography and History of Science. In: Whittaker, R.; O'Donnell; McCabe, A. (eds.). Language and Literacy: Functional Approaches. London: Continuum. p. 266-281.

Hunt, Celia; Sampson, Fiona. 2006. Writing: Self \& Reflexivity. New York: Palgrave Macmillan.

Liberali, Fernanda. 2004. Getting ready to conduct a reflective session. the ESPecialist. São Paulo: PUC, v. 25. n. especial, p. 23-38. 
Magalhães, Maria; Calani, Maria. 2005. Reflective sessions: a tool for teacher empowerment. Revista Brasileira de Linguística Aplicada. Belo Horizonte: UFMG/ALAB, v. 5. n. 1, p. 135-160.

Malinowski, Bronislaw. 2012. A Scientific Theory of Culture and Other Essays. United Kingdom: Read Books.

MarTin, James; WhITE, Peter. 2005. The Language of Evaluation: Appraisal in English. New York: Palgrave Macmillan.

Matthiessen, Christian; Teruya, Kazuhiro; Lam, Marvin. 2010. Key Terms in Systemic Functional Linguistics. London: Continuum.

Melo, Lívia. 2014. Práticas de citação na escrita de relatórios de estágios supervisionados. Tese de Doutorado (Programa de Pós-Graduação em Letras: Ensino de Língua e Literatura). Araguaína: Universidade Federal do Tocantins (em andamento).

. 2011. Relatórios de estágio supervisionado em ensino de língua inglesa: práticas auto-reflexivas de escrita. $148 \mathrm{f}$. Dissertação (Mestrado em Ensino de Língua e Literatura) - Universidade Federal do Tocantins, Araguaína.

; Gonçalves, Adair; Silva, Wagner. 2013. Escrita acadêmica na escrita reflexiva profissional: citações de literatura científica em relatórios de estágio supervisionado. Bakhtiniana: Revista de Estudos do Discurso. São Paulo: PUC/SP, v. 8, n. 1, p. 95-119.

MоттA-Roтн, Désirée. 2011. Questões de metodologia em análise de gênero. In: Karwoski, A. M.; Gaydecka, B.; Brito, K. S. (orgs.). Gêneros textuais: reflexões e ensino. $3^{\mathrm{a}}$. Ed. São Paulo: Parábola Editorial. p. 153-173.

Ninin, Maria; BARBARA, Leila. 2013. Engajamento na perspectiva linguística sistêmico-funcional em trabalhos de conclusão de curso de Letras. Trabalhos em Linguística Aplicada. Campinas: Unicamp/ IEL, v. 52, n. 1, p. 127-146.

Pereira, Bruno. 2014. Professores em formação inicial no gênero relatório de estágio supervisionado: um estudo em licenciaturas paraenses. 140f. Dissertação (Mestrado em Letras: Ensino de Língua e Literatura). Campus Universitário de Araguaína - Universidade Federal do Tocantins, Araguaína.

Perrenoud, Philippe. 2002. A prática reflexiva no ofício de professor: profissionalização e razão pedagógica. Porto Alegre: Artmed.

ScHÖN, Donald. 1993. The reflective practitioner: how professional think in action. London: ASHGATE.

SiLVA, Wagner; Espindola, Elaine. 2014. Schoolteachers represented in pre-service teacher's reflexive academic writing. Hong Kong: The Hong Kong Polytechnic University. 
Sistêmico-Funcional. Revista da ANPOLL. Florianópolis: UFSC, v. 2, n. 34, p. 159-307.

; ReIS, Naiane dos. 2014. Construção de práticas de letramento digital na formação inicial do professor de língua materna. In: Kleber Aparecido da Silva; Júlio César de Araújo (orgs.). Letramentos, Discursos e Identidades: novas perspectivas. Campinas: Pontes (no prelo).

2013. Escrita do gênero relatório de estágio supervisionado na formação inicial do professor brasileiro. Revista Brasileira de Linguística Aplicada. Belo Horizonte: UFMG/ALAB, v. 13, n. 1, p. 171-195.

.2012a. Proposta de análise textual-discursiva do gênero relatório de estágio supervisionado. DELTA: Documentação de Estudos em Linguística Teórica e Aplicada. São Paulo: PUC/SP, v. 28, n. 2, p. 281-305.

2012b. Letramento do professor em formação inicial: interdisciplinaridade no estágio supervisionado da licenciatura. Campinas: Pontes Editores.

; FAJARDO-Turbin, Ana. (orgs.). 2012. Como fazer relatórios de estagio supervisionado. Brasília: Liber Livro.

; Mendes, Aliny. 2012. Reescrita na formação inicial de professores: um estudo da produção escrita do gênero relatório de estágio supervisionado. Caderno de Letras. Pelotas: UFPEL, v. 18, p. 134-155.

; Melo, Lívia. 2008. Relatório de estágio supervisionado como gênero discursivo mediador da formação do professor de língua materna. Trabalhos em Linguística Aplicada. Campinas: Unicamp/ IEL, v. 47, n. 1, p. 131-149.

; Pereira, Bruno. 2013. Letramento acadêmico no estágio supervisionado da licenciatura. In: Raído, Dourados: Editora da UFGD, v. 7, n. 13, p. 37-60.

; SANTos, Janete; Mendes, Aliny. 2014. Investigação científica na docência universitária: reescrita como uma atividade sustentável na licenciatura. Raído, Dourados: Editora da UFGD, v. 8, n. 15, p. 71-93.

Thомpson, G. 2014. Introducing Functional Grammar. $3^{\text {rd }}$. Ed. London: Routledge.

VIAN JR, Orlando. 2009. O sistema de avaliatividade e os recursos para gradação em Língua Portuguesa: questões terminológicas e de instanciação. DELTA: Documentação de Estudos em Linguística Teórica e Aplicada. São Paulo: PUC/SP, v. 25, n. 1, p. 99-129. 
31.1

2015

ZEICHNER, Kenneth. 2008. Uma análise crítica sobre a "reflexão" como conceito estruturante na formação docente. Educação e Sociedade: Revista de Ciência da Educação. Campinas: Unicamp, v. 29, n. 103, p. 535-554. 